\title{
Do productive firms get external finance? Evidence from Chinese listed manufacturing firms
}

\author{
Minjia Chen ${ }^{\mathrm{c}, *}$, Roman Matousek ${ }^{\mathrm{a}, \mathrm{b}, \mathrm{c}}$ \\ ${ }^{a}$ School of Business and Management, Queen Mary University of London, United Kingdom. \\ ${ }^{\mathrm{b}}$ Othman Yeop Abdullah Graduate School of Business (OYAGSB), University Utara Malaysia, UUM, Sintok, Malaysia. \\ ${ }^{\mathrm{c}}$ Nottingham University Business School, University of Nottingham, United Kingdom.
}

\section{A R T I C L E I N F O}

JEL classification:

D22

D24

G32

\section{Keywords:}

Capital structure

Leverage

Firm productivity

TFP

Labour productivity

External finance

Long term debt

New issue of equity

Exporters

Ownership

\begin{abstract}
A B S T R A C T
Due to information asymmetry problem in financial markets good quality firms often find it difficult to prove to external finance providers about their true quality and to distinguish themselves from bad quality firms. We argue that instead of sending indirect signals to financial market good quality firms could focus on improving their productivity to obtain external finance. Besides relying solely on firms' balance sheet information external finance providers using firms' TFP or labour productivity information would have a true knowledge of firms' efficiency and risk. Overall, using a panel of 1591 Chinese listed manufacturing firms between 2003 and 2016 we find that productivity measured by TFP or labour productivity is statistically and economically important and positive in determining firms' external finance, i.e. total leverage, new issue of equity and long-term debt. We find that productivity is helpful for firms to raise new equity finance, but only some weak results for total leverage and long-term debt. Such results hold for both the whole sample and private firm sample. We also find that large and/or old firms and exporting firms are able to make better use of their productivity to gain external finance than their respective counterparts, i.e. small young firms and non-exporting firms. The causality of the regression results is also confirmed by difference-in-difference tests using an exogenous industrial policy shock.
\end{abstract}

\section{Introduction}

It is well recognised that financial market imperfections result in good quality firms being unable to raise external funds for their profitable projects. There has been extensive research that focus on firms' financing behaviour under the assumption that firms are adversely affected by financial market imperfections. Studies have also been investigating how legal and institutional advancement may improve the market imperfection situation and consequently improve the accessibility of external finance for all firms in the market (e.g. Bancel \& Mittoo, 2004; Booth, Aivazian, Demirgüç-Kunt, \& Maksimovic, 2001; Rajan \& Zingales, 1995; Öztekin \& Flannery, 2012). Anecdotal evidence seems to show that financial institutions tend to base their lending decisions on bank relations or firms' balance sheet information, which is subject to window dressing. Tan, Zhu, Zeng, and Gao (2014) does find evidence that non-state Chinese listed firms manipulate their earnings to meet the performance targets required by the stock market in order to raise equity finance. Johan and $\mathrm{Wu}(2014)$ also find that the quality of the lender-borrower relationship makes no contribution to small firms' access to debt in China or Canada. Therefore, external financial resources do not necessarily go to the truly efficient firms. However, little is known about how heterogeneous firms can distinguish themselves from others and prove to external finance providers about their true worthiness, ${ }^{1}$ and therefore suffer less from the information asymmetry problem under given institutional environment. In other words, little is known about whether truly good firms do get external finance. We try to fill in this gap in this paper.

In recent years, the relationship between firms' productivity and their finance has attracted increasing attention among scholars for most major economies, e.g. Chen and Guariglia (2013) for China, Krishnan, Nandy, and Puri (2015) for the US, Ferrando and Ruggieri (2018) for Euro area countries. Most recently, Egger and Keuschnigg (2017)'s model shows that banks are only willing to lend to firms with a minimum productivity level, which will enable firms to thrive in the

\footnotetext{
* Corresponding author at: Nottingham University Business School, University of Nottingham, Jubilee Campus, Wollaton, Nottingham NG8 1BB, United Kingdom.

E-mail addresses: minjia.chen@nottingham.ac.uk (M. Chen),r.matousek@qmul.ac.uk (R. Matousek).

${ }^{1}$ Our argument is related but very different from the signalling theory (Ross, 1977), which suggests issuing debt is firms' signal of high quality to the markets. We discuss this in more details below.
} 
market and allow banks to break even from the lending. Neuhann and Saidi (2018) find from US public firms that with better informational economy of scale, i.e. more information about firms became available to banks, following the deregulation of universal banks (which conduct both commercial and investment bank businesses), universal banks finance riskier but more productive firms. However, none of these papers has tested directly whether high productivity itself would help firms to be more attractive to banks to get loans.

This paper aims to further contribute to the empirical research on firms' financing behaviour. In our study we explore how firms' productivity, which is measured by either total factor productivity (TFP) or labour productivity, can be used as a relevant indicator of firms' true value and helps firms to raise external finance. In doing so, we use Chinese listed manufacturing firms' data.

To our best knowledge, this paper is the first attempt to test whether productivity helps firms to raise external finance, and whether better firms do get relatively more external finance. Consequently, we may be able to identify productivity as a good indicator of firms' quality from the perspective of external finance providers. A reliable indicator of firms' quality may help to overcome information asymmetry problem in the financial markets to some extent and channel external finance into efficient firms. Our research effectually also contributes to the firm capital structure literature, which often debates about what drives firms' financing choices. We offer an alternative view. Rather than being a choice of firms due to cost minimisation as suggested by the pecking order theories, static trade off theories and market timing theories, our research implies that firms' capital structure is also determined by their ability of raising finance from outsiders, which may also vary across different forms of external finance. In other words, our results would show that firms' capital structure is not only determined by what firms want, but also what they are able to have. The application on the Chinese listed manufacturing firm data provides a suitable testing environment for this research.

The rest of the paper is organised as follows: Section 2 reviews the relevant literature and describes our theoretical idea. Section 3 presents the equations for empirical tests and discusses our method. Section 4 describes our data. Section 5 discusses the regression results. Section 6 further verifies the causality of our results, and finally Section 7 concludes.

\section{A brief literature overview}

There has been an increasing interest in the relationship between productivity and finance both at aggregate and firm level (see Heil, 2018, for a survey). While most studies focus on macro factors, Gatti and Love (2008), Moreno-Badia and Slootmaekers (2009), Chen and Guariglia (2013), Krishnan et al. (2015), Ferrando and Ruggieri (2018) among others find evidence of direct link between firms' finance and productivity, as finance may enable firms to optimise operations and carry out productivity enhancing investments. There is also limited research on the reverse link. As mentioned above, Egger and Keuschnigg (2017) and Neuhann and Saidi (2018) find that banks are willing to lend to productive firms even if they are riskier. Besides, Gonzalez and James (2007) using a panel of US listed firms shows that technology firms have easier access to bank lending, and current earnings and cash flows are significantly less important in determining such finance for technology firms than for non-technology firms. It is not unreasonable to interpret their results as that technology, a likely proxy for productivity, has a positive effect on firms' access to bank lending. However, none of these researches has provided any direct evidence whether productivity helps firms to raise external finance, which we do in this paper.

In the finance and growth literature a large number of studies, at both aggregate (e.g. Beck, Levine, \& Loayza, 2000; Carlin \& Mayer, 2003) and firm levels (e.g. Brown, Fazzari, \& Petersen, 2009; Guariglia, Liu, \& Song, 2011), find that a sound financial system or good accessibility of financial resources enable growth (e.g. Ayyagari, Demirgüç-Kunt, \& Maksimovic, 2011; King \& Levine, 1993). On the other hand, in the long-term, economic growth is largely a reflection of rising productivity, as it drives growth through its direct effects such as improved effort and efficiency. Krugman (1990, 1994, 1997) reached his famous conclusion that "productivity isn't everything, but in the long run it is almost everything", when examining the relationship between productivity improvement and economic growth. In this paper, what we try to test potentially may bridge the two areas of literature together. Our finding may show an indirect channel that productivity drives growth through enabling external finance.

The signalling theory developed by Ross (1977) suggests that managers have incentives to signal the market of firms' high quality by choosing high leverage, as issuing debt can expose firms to costly financial distress (Ovtchinnikov, 2010). Though Ross's model also suggests that firms' high quality would be associated with high leverage, Ross models leverage as a choice of firms, whereas we consider that firms are eager to demonstrate their qualities in order to compete for external finance. In his theory, the incentive for signalling is primarily managers' personal gains, whereas we consider that the incentive for firms to prove their true quality is to obtain external finance. Yet in the signalling theory, quality is not defined in terms of observable variables (Smith Jr. \& Watts, 1992), whereas we specify quality as firms' productivity.

Our study also partially overlaps the research on a role for productivity in the firm capital structure literature. To formally test the effects of productivity on firms' external finance, our empirical model is largely derived from the established capital structure literature. The main ones predicting the observed behaviour of utilising external finance by a value-maximising firm include the Myers and Majluf (1984)'s pecking order theory, the static trade-off theory and the market timing theory (Baker \& Wurgler, 2002). Also due to managerial optimism (Heaton, 2002) whether firms accept positive net present value projects may depend on whether the projects require external finance. Such financing decisions are only related to firms' free cash flow and not influenced by asymmetric information and rational agency costs (Heaton, 2002). According to the agency theory, firms' capital structure is likely an optimal response of partially entrenched and risk-neutral managers who balance between overinvestment and the risk of takeovers (Zwiebel, 1996). Morellec's (2004) real option model also shows capital structure as risk-neutral managers' choice between investment and retaining control. Mande, Park, and Son (2011) argue that good corporate governance reduces firms' agency costs and consequently increases firms' likelihood of issuing equity finance. Crespí and MartínOliver (2015) also argue the reason that family firms have easier access to debt than non-family firms is due to their lower agency cost.

Nevertheless empirical evidence of those studies is inconclusive (e.g. Fama \& French, 2002; Frank \& Goyal, 2003; Sarkar \& Zapatero, 2003). It is possibly attributable to statistical testing difficulties and the practical interpretation of those hypotheses (e.g. Leary \& Roberts, 2010) and seem to depend on the particular stochastic process assumed for firms' earnings, i.e. internal source of finance (Sarkar \& Zapatero, 2003). The magnitude and persistency of the impact of market timing on capital structure are also challenged by some empirical findings, such as Alti (2006), and Hovakimian (2006). There is also evidence that firms often actually issue debt and equity simultaneously to reduce variation in their capital structure (e.g. Billingsley, Smith, \& Lamy, 1994).

However, so far the capital structure literature includes no explicit role for firms' productivity. We argue that firms' productivity demonstrates firms' true value and therefore helps firms to raise external finance through the channel of mitigating information asymmetry. Our results would be more consistent with the pecking order theory, i.e. we confirm that more productive firms are able to utilise finance of higher pecking order or more expensive external finance.

A stream of research finds that legal and institutional improvement 
in a country can benefit the country's financial development and accessibility for borrowers overall (e.g. Beck, Demirgüç-Kunt, \& Levine, 2003). Vanacker, Heughebaert, and Manigart (2014) find better shareholder protection and bankruptcy laws help new technologybased firms in six European countries to gain better probability to access and have more amount of equity and debt finance. Further, Feng, $\mathrm{Fu}$, and Kutan (2019) find evidence of double-edged results of government intervention in China, which promotes firms' access to loans but also forces firms to make bribe payments to gain this financial access. Nevertheless, these authors' focus is on macro environment rather than individual firms.

Financial institutions may be tempted to use firm's balance sheet information, such as profitability, financial health, previous loan payment history, as market signal of credit worthiness and to determine the eligibility of a firm for access to loans, since these information can be easily monitored (see Brealey, Leland, \& Pyle, 1977; Fama, 1984). However, balance sheet information, on the other hand, is easily manipulated and often cannot convince outsiders about the true value of a firm (Tan et al., 2014). Institutions and firms relying on accounting information are deemed to suffer from information asymmetry problem. We argue that productivity, especially TFP, is a good indicator of firms' true worthiness and cannot be easily manipulated. It helps firms to suffer less from information asymmetry problem in the financial markets. Therefore, we want to find out whether productive firms do get more external finance and in what forms of finance. To our knowledge, the existing research in the areas of firms' capital structure mainly focuses on testing firms' financing behaviour given the disadvantages of information asymmetries and agency problems etc., but surprisingly little is known on whether and how firms can relieve such disadvantage themselves so that they can optimise their financing and production strategy.

Finally, the seminal work of "Growing like China" by Song, Storesletten, and Zilobotti (2011) shows that Chinese firms have experienced an enormous productivity growth and the country has transformed from a virtually closed economy to a world manufacturing centre in just three decades, and yet its financial sector is largely underdeveloped and frictional. These authors' theoretical model suggests that Chinese manufacturing firms are especially interesting for studying the relationships between productivity and finance under China's economic and financial system. The Chinese stock market opened in 1990, and only became more regulated from 1999, when the China Securities Acts was put into effect. Firms in China are known to face difficulty in raising finance (e.g. Allen, Qian, \& Qian, 2005; Guariglia et al., 2011; Poncet, Steingress, \& Vandenbussche, 2010). Hence, the Chinese context would precisely suit our research and we test whether higher productivity brings more external finance to listed Chinese firms, which are likely to have relatively better quality than other non-listed firms and already have the access to equity finance. The implications found from listed firms can be easily extended to other firms, as the latter would typically suffer more from information asymmetries.

\section{The model and estimation methods}

In order to test the effects of productivity on firms' external finance, we first propose the theoretical idea of a framework describing how firms' productivity may link to their external finance in a sensible way. Then we establish empirical regression models which are implied by the framework and consistent with exiting theories.

\subsection{The proposed methodological framework}

Adopting an assumption that productivity fundamentally defines heterogeneity across firms (e.g. Melitz, 2003), our key novel idea is that in a competitive market where firms maximise profits and external

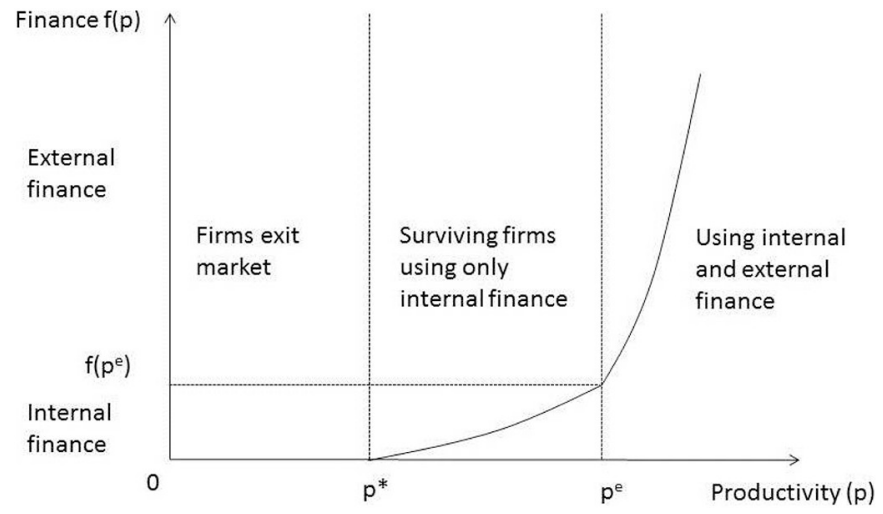

Fig. 1. Firm productivity and finance.

Notes: $\mathrm{p}^{*}$ is firms' surviving productivity, and $\mathrm{p}^{\mathrm{e}}$ is the minimum level of productivity when firms may start to raise external finance.

finance providers are risk neutral or averse, firms which do not reach a critical level of productivity have to exit the market. Firms with an intermediate level of productivity are able to survive in the market, but can only rely on their own internal finance, because they are rationed by external finance providers who disbelieve their ability in generating sufficient cash flow and find them too risky to lend to or invest in. Firms with a high level of productivity not only grow in the market, but also have access to external financial markets, where finance providers find them trustworthy. This idea is illustrated in Fig. 1, where $p^{*}$ and $p^{e}$ are the critical productivity levels when firms can survive and start to access external finance respectively. This is consistent with Egger and Keuschnigg (2017)'s model, which shows banks can only break even if they lend to firms with a minimum productivity. This framework mainly builds upon the literature of capital market imperfections, and we assume the effect of productivity is through the channel of relieving information asymmetry between firms and external financial providers, which is consistent with Neuhann and Saidi (2018)'s findings. Neuhann and Saidi (2018) find that when more information becomes available, banks are willing to lend to productive firms even if they are riskier.

This framework shows that exposure to imperfect financial markets induces only the most productive firms to access external finance while simultaneously forcing the least productive firms to exit. Both the exit of the least productive firms and the additional investment that the most productive firms are able to undertake using the external finance, reallocate market shares towards the more productive firms, and eventually promote an aggregate productivity increase. Our framework has the empirical implication that firms' productivity should have a positive effect on their ability in raising external funds through mitigating information asymmetry problem. Accordingly, if firms have demand of external finance for their investment opportunities, we should observe that higher productivity helps firms to keep higher leverage, keep higher debt ratio, and issue more new equity (or some combination of them). ${ }^{2}$

\subsection{Empirical model}

Our idea above may lead to the regression model between external finance and productivity below. Except firms' productivity, the variables in our equations have been well documented in the capital

\footnotetext{
${ }^{2}$ This is related but different from Ding, Kim, and Zhang (2018)'s interpretation. Ding et al. (2018) use TFP as a supply side measure of firms' investment opportunities, and found TFP has positive effects on firms' investment. In their case, firms may or may not need/use external finance for their investment. Whereas in our case we explicitly test the situation when firms has the demand of external finance.
} 
structure literature in determining firms' external finance.

$$
\begin{aligned}
& \text { extfinance }_{i t} \\
& \begin{aligned}
=a+ & b_{1} \text { extfinance }_{i, t-1}+b_{2} \text { sales }_{i t-1}+b_{3} \text { assetgrowth }_{i t-1}+b_{4} \text { tangibility }_{i t-1} \\
& +b_{5} \text { roa }_{i t-1}+b_{6} \text { dep }_{i t-1}+b_{7} \text { productivity }_{i t-1}+v_{j}+v_{t}+v_{p}+v_{o}+e_{i t}
\end{aligned}
\end{aligned}
$$

The extfinance variables, including firm $i$ 's total leverage, i.e. the ratio of total liabilities to total assets, new issue of equity to total assets ratio, ${ }^{3}$ and long-term debt to total assets ratio at time $t$, are used in separate regressions. We use the same model to compare the effects of productivity on three forms of external finance. sales is the logarithm of firm's real sales; assetgrowth is the growth of firm's net fixed assets in logarithm form from time $t-1$ to time $t$; tangibility is firm's ratio of total tangible assets to total assets; roa is firm's return on assets, which is the ratio of net profit to total assets; dep is firm's depreciation to total assets ratio; productivity includes three measures of firm's TFP and firm's labour productivity, which is firm's real sales per employee, ${ }^{4}$ in separate regressions. $v_{j}, v_{t}, v_{p}$ and $v_{o}$ are two-digit industry dummies, year dummies, province dummies, which indicate firms' location, and firms' ownership dummies respectively. $e_{i t}$ is an idiosyncratic error term.

The estimation of TFP is practically difficult as econometricians cannot observe firms' production decisions and therefore face problems such as endogenous input choices by firms, and different technology employed by a firm with multiple products. Therefore, we apply three popular methods of TFP estimation ${ }^{5}$ in order to verify the robustness of our results. First, we use the Levinsohn and Petrin (2003) (LP thereafter) method using the revenue function. It uses firms' intermediate inputs to control for unobserved productivity shock in order to address the problem of endogenous input choices, as well as the problem of non-negative and lumpy investment, which was used as the proxy by Olley and Pakes (1996) (OP thereafter). Second, we use the Wooldridge (2009)'s GMM method, which further improves the simultaneity issues in the estimation by LP or OP. Then we use the more recent Ackerberg, Caves, and Frazer (2015) (ACF hereafter) method, which further addresses the functional dependence problem suffered by LP and OP methods by inverting the investment or intermediate demand functions unconditional on the labour input. They also argue that comparing to Wooldridge (2009) their method has the advantage of allowing a more general data-generating process.

Though TFP is believed to be a good measure of manufacturing firms' productivity (see Syverson, 2011 for a survey), it is not easily observable or comparable by external finance providers. Therefore, we also test Eq. (1) using labour productivity, which provides a further check of the robustness of our findings.

Direct bankruptcy costs (Warner, 1977) and borrowing costs associated with information asymmetries in the financial markets (Ferri \& Jones, 1979; Titman \& Wessels, 1988) mean that it is easier for large firms to borrow, i.e. to keep high leverage. However, on the other hand, firms with large sales have more retained earnings, which is a cheap internal source of finance, and thus have less need of external finance. We use firms' real sales to proxy firm size and expect it to have either positive or negative coefficient.

The inclusion of firms' net fixed asset growth is to capture firms' growth opportunities. The relationship between firms' growth opportunities and leverage may vary. High growth opportunities may lead to worse shareholder-bondholder conflict (Myers, 1977), and assets substitution and dilution (Jensen \& Meckling, 1976). Therefore, firms reduce leverage as a response to control the costs associated with these problems. Titman and Wessels (1988) argue that expected future

\footnotetext{
${ }^{3}$ We define the new equity issues ratio following Baker, Stein, and Wurgler (2003).

${ }^{4}$ More detailed variable definitions can be found in the Appendix A.2.

${ }^{5}$ When estimating firms' TFP, we assume endogenous technological progress following Romer (1990), and Aghion and Howitt (1998).
}

growth should be negatively related to long-term debt level due to agency cost. However, the agency problem is mitigated if firms issue short-term debt (Myers, 1977). Under the pecking order theory, if firms' priority is current period investment, firms' leverage will increase with higher growth opportunities, as firms would finance the current investment projects with increased debt (Ovtchinnikov, 2010). However, if firms are more concerned with future investment, they would prefer to keep current leverage low and reserve their debt capacity in anticipation of future finance for investment (Ovtchinnikov, 2010). Using a dynamic model of investment and financing, Sundaresan, Wang, and Yang (2015) also show that a rational firm significantly lowers its leverage in anticipation of future growth. Thus, the sign of the asset growth variable in our model may be uncertain.

Tangible assets can be used as collateral by lenders and thus firms' opportunity to engage in asset substitution is reduced (Stulz \& Johnson, 1985), which eases the agency problem. This suggests a likely positive effect of assets tangibility on leverage. However, when firms' leverage is not too high, managers may tend to consume more than the optimal level of perquisites, which suggests a negative relation between collateralisable (tangible) capital and leverage (Titman \& Wessels, 1988). Hence, the sign of tangibility variable may be also uncertain. We also expect the effect of tangibility on firms' equity finance would be uncertain too. Investors can claim firm's remaining assets after lenders in case of bankruptcy. On the other hand, investors may prefer firms to have low tangibility so that more funds may be freed up for profitable investment, which benefits shareholders more directly than debtholders.

Return on assets (ROA) is used to measure firms' profitability. According to the pecking order theory, profitable firms would have less need to finance investment projects with more expensive external finance, and thus have lower leverage. Profitable firms may also use internal finance to repurchase outstanding equity when their share price is low according to market timing theory, and have less need of issuing new equity. On the other hand, under the trade-off theory more profitable firms have lower potential costs of financial distress, and thus can utilise more debt to shield against income tax and control the agency cost of free cash flow (Jensen, 1986). Thus, debt is more attractive and affordable for more profitable firms, i.e. leverage is higher. The overall effect of profitability depends on which incentive dominates.

DeAngelo and Masulis (1980) suggest that firms' depreciation is a corporate tax shield substitute for debt. If firms utilise their depreciation deductions to shield corporate tax, firms may not try to use debt for the same purpose given concerns of financial distress risk. This follows the logic of the trade-off theory. Therefore, we may expect a negative relationship between depreciation and leverage. Huang and Song (2006) find a negative relation between such tax shield and the leverage of Chinese listed firms. However, the effect of depreciation on firms' new equity might be opposite. High depreciation leads to high cost in firms' income statement, which leads to lower net income and lower retained earnings. According to the market timing theory, when firms are short in their internal source of finance, they have stronger incentives to issue new equity. Therefore, we may expect a positive effect of depreciation on firms' new equity.

Industry and time dummies are common in the literature to control for industry specific characteristics and time effects. There has been numerous empirical evidence of cross-sectional differences in firms' capital structure related to industrial effects (e.g. Titman \& Wessels, 1988), and positive relation between firms' capital structure and the average of their industry (e.g. Bradley, Jarrell, \& Kim, 1984). The province dummies are to control the fixed effect associated with firm location. The Chinese economy has a strong location dimension, where typically the coastal provinces have more advanced economies than others do. Provincial authorities have numerous local policies that shape the economic and legal environment for firms. 
Ownership dummies ${ }^{6}$ account for various managerial incentives that may affect firms' capital structure especially in the Chinese context. For example, it is often believed that state firms have easier access to external finance due to the fact that in the event of bankruptcy state firms are likely to be bailed out by public finance. Foreign firms often have access to finance abroad such as funds from their parent companies and foreign financial institutions, whereas private firms in China are discriminated in financial markets (Allen et al., 2005). An, Pan, and Tian (2014) find evidence from Chinese listed firms that ownership structure has a strong impact on the collateral requirement of firms for their loans.

The Chinese stock market started with only state firms in the early 1990s, and the state firms dominated the market for many years. As the privatisation process goes on, both the proportion of state firms in the stock market and the proportion of state shares in firms keep reducing. In our sample, the proportion of state firms drops each year from over $60 \%$ in 2003 to about $30 \%$ in 2016 . To further eliminate the influence of financial privileges that firms with some ownership types may enjoy, we also test Eq. (1) with domestic private firm sample only. If our results are also valid for the most disadvantaged group of domestic private firms, we may be more confident that the productivity effects are not driven by some firms' ownership privilege in obtaining external finance.

$$
\begin{aligned}
& \text { extfinance }_{i t} \\
& \begin{aligned}
=a+ & b_{1} \text { extfinance }_{i, t-1}+b_{2} \text { sale }_{i t-1}+b_{3} \text { assetgrowth }_{i t-1}+b_{4} \text { tangibility }_{i t-1} \\
& +b_{5} \text { roa }_{i t-1}+b_{6} \text { dep }_{i t-1}+b_{71} \text { productivity }_{i t-1} \times \text { Type } \\
& +b_{72} \text { productivity }_{i t-1} \times(1-\text { Type })+v_{j}+v_{t}+v_{p}+v_{o}+e_{i t}
\end{aligned}
\end{aligned}
$$

We then further split the full sample of firm-years by their size and age together, and their export status by estimating Eq. (2). Type1 is a dummy variable indicating firms being small and young ${ }^{7}$ in industry $j$ and year $t$, and exporting products overseas in year $t$ in separate regressions. Beck, Demirgüç-Kunt, Laeven, and Maksimovic (2006) find strong evidence from a large panel of firms from 80 countries that size and age are useful indicators of financing constraints. Casey and O'Toole (2014) also find from Euro area counties that size and age influence firms accessibility of different types of finance, i.e. larger and older firms are more likely to use finance of higher pecking order. Thus, we try to find out whether productivity is more helpful for small young firms or for larger and/or older firms.

Only productive firms are able to export due to the large sunk cost of exporting (Melitz, 2003). Therefore, export status could be a natural indicator of firms' quality. Less financial constraints or more availability of finance enables export as well (see Wagner, 2014 for early survey, and Muûls, 2015 among others). The export, productivity and finance nexus has also been an increasingly popular research area recently, e.g. Egger and Keuschnigg (2017). We are the first trying to explore further by testing whether exporters with high productivity get more external finance. Both size age and exporting status dimensions somewhat indicate firms' perceived or true quality. We are interested to find out how firms' productivity interact with these measures and exert any effect on their ability of increasing external finance.

Our regression models are likely to suffer from endogeneity problems, and we therefore lag all the independent variables by one period to treat the problem. We further control for the possible simultaneity

\footnotetext{
${ }^{6}$ We include 5 ownership dummies, i.e. 1. central state owned, 2. lower level state owned, 3. domestic private, 4. foreign including Hong Kong, Taiwan and Macau, 5 . others, which are defined by firms' ultimate controlling shareholders.

${ }^{7}$ A firm is defined as small young if its real sales is ranked in the bottom 50 percentile of the real sales distribution of all firms in the same 2-digit industry and in the same year, and if its age is ranked in the bottom 50 percentile of the age distribution of all firms in the same 2-digit industry. Firm age is defined at the beginning of the year.
}

and endogeneity problems by using the system generalised method of moments (GMM), in which we treat all the regressors as endogenous and instrument them using their own lagged variables. ${ }^{8}$ Year dummies, two-digit industry dummies, province dummies and ownership dummies are included in all the regressions and instrument sets. Since finance measures are found to be able to increase firms' TFP (e.g. Chen \& Guariglia, 2013), we cautiously make sure if productivity helps firms to increase their external finance, the effects are not driven simply by the correlations between the two variables. We therefore further establish the casual effect of productivity on external finance by utilising the difference-in-difference method following an exogenous industrial policy shock.

\section{Data and descriptive statistics}

\subsection{Data sample}

Our data is from the China stock market financial statements database (CSMAR), which contains financial statement information for all listed firms in China's stock market. Due to accounting standards and stock market regulation changes, and data collection issues, some of our key variables only became available from $2003 .{ }^{9}$ Our sample firms are manufacturing firms located in 30 provinces or province-equivalent municipal cities of China.

To control for the bias caused by outliers we winsorise the $1 \%$ tails of the distribution of all variables included in our regressions except the following. Only the top $1 \%$ for the long-term debt (only in the longterm debt ratio regressions) and depreciation, and their observations with negative values are winsorised. Only the bottom $1 \%$ and the values larger than 1 of tangibility are winsorised. We leave out firms with less than three-year consecutive observations, which is a common practice for dynamic models, as well as firms that do not have complete information on our regression variables. Finally, our unbalanced panel covers 1591 listed firms with 12,618 firm-year observations. Our dynamic model equation leaves our sample ranging from 2003 to 2016. Observations in each year range from a minimum of 527 in 2016 to a maximum of 1468 in $2015 .^{10}$

\subsection{Descriptive statistics}

Column 1 of Table 1 shows the descriptive statistics of all the variables in the whole sample, and column 2 to 4 report the statistics of private and the rest of the firm-years. About $45 \%$ of the total firm-years are private. ${ }^{11}$ The $t$-tests in column 4 , which show the significance of the mean difference between the private sample in column 2 and the rest of the sample in column 3, indicate that all variables except ACF TFP and labour productivity are significantly different between the two groups. Private firms have lower leverage, long-term debt ratio, sales, tangibility and depreciation, but they issue more new equity, grow faster, and are more profitable and more labour intensive comparing with other firms. Their productivity comparing with other firms is however ambiguous. The long-term debt dummy shows the proportion of firms having positive long-term debt. A sizable proportion of firms in all categories do not have any long-term debt at all, and a significantly smaller proportion of private firms have any long-term debt than other firms, which may be due to their inability to borrow, as they are more likely to be discriminated in the Chinese financial market. This is

\footnotetext{
${ }^{8}$ We use the lagged level variables of the endogenous regressors in the differenced equations and the lagged difference variables in the level equations as the instruments.

${ }^{9}$ Export data appears in various forms for different firms and is extracted from a set of assorted firm level information.

${ }^{10}$ See the Appendix A.1 for more information on the structure of our panel.

${ }^{11}$ Firms' ownerships are defined by their ultimate controlling shareholder.
} 
Table 1

Summary statistics.

\begin{tabular}{|c|c|c|c|c|c|c|c|c|c|c|}
\hline & All firm-years & Private & Others & $\begin{array}{l}\text { Diff. } \\
\text { (p-value) }\end{array}$ & Small \& young & Others & $\begin{array}{l}\text { Diff. } \\
\text { (p-value) }\end{array}$ & Exporters & Non-exporters & $\begin{array}{l}\text { Diff. } \\
\text { (p-value) }\end{array}$ \\
\hline & (1) & (2) & (3) & (4) & (5) & (6) & (7) & (8) & (9) & (10) \\
\hline Leverage & $\begin{array}{l}0.568 \\
(0.346)\end{array}$ & $\begin{array}{l}0.525 \\
(0.365)\end{array}$ & $\begin{array}{l}0.603 \\
(0.325)\end{array}$ & 0.000 & $\begin{array}{l}0.469 \\
(0.307)\end{array}$ & $\begin{array}{l}0.600 \\
(0.352)\end{array}$ & 0.000 & $\begin{array}{l}0.553 \\
(0.326)\end{array}$ & $\begin{array}{l}0.588 \\
(0.370)\end{array}$ & 0.000 \\
\hline New equity & $\begin{array}{l}0.070 \\
(0.240)\end{array}$ & $\begin{array}{l}0.089 \\
(0.276)\end{array}$ & $\begin{array}{l}0.054 \\
(0.205)\end{array}$ & 0.000 & $\begin{array}{l}0.054 \\
(0.199)\end{array}$ & $\begin{array}{l}0.075 \\
(0.252)\end{array}$ & 0.000 & $\begin{array}{l}0.075 \\
(0.241)\end{array}$ & $\begin{array}{l}0.062 \\
(0.239)\end{array}$ & 0.003 \\
\hline Long-term debt & $\begin{array}{l}0.054 \\
(0.094)\end{array}$ & $\begin{array}{l}0.041 \\
(0.083)\end{array}$ & $\begin{array}{l}0.064 \\
(0.101)\end{array}$ & 0.000 & $\begin{array}{l}0.039 \\
(0.080)\end{array}$ & $\begin{array}{l}0.059 \\
(0.098)\end{array}$ & 0.000 & $\begin{array}{l}0.049 \\
(0.086)\end{array}$ & $\begin{array}{l}0.060 \\
(0.103)\end{array}$ & 0.000 \\
\hline Long-term debt dummy & $\begin{array}{l}0.586 \\
(0.493)\end{array}$ & $\begin{array}{l}0.498 \\
(0.500)\end{array}$ & $\begin{array}{l}0.657 \\
(0.475)\end{array}$ & 0.000 & $\begin{array}{l}0.458 \\
(0.498)\end{array}$ & $\begin{array}{l}0.628 \\
(0.483)\end{array}$ & 0.000 & $\begin{array}{l}0.593 \\
(0.491)\end{array}$ & $\begin{array}{l}0.575 \\
(0.494)\end{array}$ & 0.039 \\
\hline logtfp (LP) & $\begin{array}{l}1.152 \\
(0.231)\end{array}$ & $\begin{array}{l}1.187 \\
(0.245)\end{array}$ & $\begin{array}{l}1.123 \\
(0.216)\end{array}$ & 0.000 & $\begin{array}{l}1.107 \\
(0.232)\end{array}$ & $\begin{array}{l}1.167 \\
(0.229)\end{array}$ & 0.000 & $\begin{array}{l}1.144 \\
(0.194)\end{array}$ & $\begin{array}{l}1.164 \\
(0.274)\end{array}$ & 0.000 \\
\hline $\begin{array}{l}\text { logtfp } \\
\text { (Wooldridge GMM) }\end{array}$ & $\begin{array}{l}2.963 \\
(0.109)\end{array}$ & $\begin{array}{l}2.956 \\
(0.245)\end{array}$ & $\begin{array}{l}2.968 \\
(0.112)\end{array}$ & 0.000 & $\begin{array}{l}2.929 \\
(0.101)\end{array}$ & $\begin{array}{l}2.974 \\
(0.109)\end{array}$ & 0.000 & $\begin{array}{l}2.973 \\
(0.102)\end{array}$ & $\begin{array}{l}2.949 \\
(0.117)\end{array}$ & 0.000 \\
\hline logtfp (ACF) & $\begin{array}{l}2.190 \\
(0.092)\end{array}$ & $\begin{array}{l}2.191 \\
(0.105)\end{array}$ & $\begin{array}{l}2.189 \\
(0.094)\end{array}$ & 0.125 & $\begin{array}{l}2.138 \\
(0.082)\end{array}$ & $\begin{array}{l}2.207 \\
(0.088)\end{array}$ & 0.000 & $\begin{array}{l}2.197 \\
(0.080)\end{array}$ & $\begin{array}{l}2.181 \\
(0.105)\end{array}$ & 0.000 \\
\hline $\log l p$ & $\begin{array}{l}8.683 \\
(1.006)\end{array}$ & $\begin{array}{l}8.691 \\
(0.960)\end{array}$ & $\begin{array}{l}8.676 \\
(1.042)\end{array}$ & 0.403 & $\begin{array}{l}8.224 \\
(0.879)\end{array}$ & $\begin{array}{l}8.834 \\
(0.999)\end{array}$ & 0.000 & $\begin{array}{l}8.734 \\
(0.894)\end{array}$ & $\begin{array}{l}8.612 \\
(1.136)\end{array}$ & 0.000 \\
\hline $\log S$ & $\begin{array}{l}16.297 \\
(1.402)\end{array}$ & $\begin{array}{l}16.014 \\
(1.274)\end{array}$ & $\begin{array}{l}16.528 \\
(1.459)\end{array}$ & 0.000 & $\begin{array}{l}15.252 \\
(0.774)\end{array}$ & $\begin{array}{l}16.643 \\
(1.392)\end{array}$ & 0.000 & $\begin{array}{l}16.503 \\
(1.266)\end{array}$ & $\begin{array}{l}16.019 \\
(1.524)\end{array}$ & 0.000 \\
\hline Asset growth & $\begin{array}{l}0.112 \\
(0.377)\end{array}$ & $\begin{array}{l}0.153 \\
(0.409)\end{array}$ & $\begin{array}{l}0.079 \\
(0.345)\end{array}$ & 0.000 & $\begin{array}{l}0.117 \\
(0.391)\end{array}$ & $\begin{array}{l}0.111 \\
(0.372)\end{array}$ & 0.388 & $\begin{array}{l}0.139 \\
(0.354)\end{array}$ & $\begin{array}{l}0.077 \\
(0.403)\end{array}$ & 0.000 \\
\hline Tangibility & $\begin{array}{l}0.276 \\
(0.160)\end{array}$ & $\begin{array}{l}0.243 \\
(0.139)\end{array}$ & $\begin{array}{l}0.303 \\
(0.171)\end{array}$ & 0.000 & $\begin{array}{l}0.281 \\
(0.145)\end{array}$ & $\begin{array}{l}0.275 \\
(0.165)\end{array}$ & 0.065 & $\begin{array}{l}0.273 \\
(0.147)\end{array}$ & $\begin{array}{l}0.281 \\
(0.177)\end{array}$ & 0.003 \\
\hline ROA & $\begin{array}{l}0.028 \\
(0.071)\end{array}$ & $\begin{array}{l}0.037 \\
(0.068)\end{array}$ & $\begin{array}{l}0.020 \\
(0.073)\end{array}$ & 0.000 & $\begin{array}{l}0.017 \\
(0.078)\end{array}$ & $\begin{array}{l}0.031 \\
(0.068)\end{array}$ & 0.000 & $\begin{array}{l}0.031 \\
(0.063)\end{array}$ & $\begin{array}{l}0.023 \\
(0.081)\end{array}$ & 0.000 \\
\hline Depreciation & $\begin{array}{l}0.028 \\
(0.017)\end{array}$ & $\begin{array}{l}0.026 \\
(0.016)\end{array}$ & $\begin{array}{l}0.031 \\
(0.018)\end{array}$ & 0.000 & $\begin{array}{l}0.026 \\
(0.015)\end{array}$ & $\begin{array}{l}0.029 \\
(0.018)\end{array}$ & 0.000 & $\begin{array}{l}0.029 \\
(0.017)\end{array}$ & $\begin{array}{l}0.028 \\
(0.018)\end{array}$ & 0.000 \\
\hline Labour intensity & $\begin{array}{l}0.106 \\
(0.072)\end{array}$ & $\begin{array}{l}0.109 \\
(0.073)\end{array}$ & $\begin{array}{l}0.103 \\
(0.071)\end{array}$ & 0.000 & $\begin{array}{l}0.118 \\
(0.067)\end{array}$ & $\begin{array}{l}0.102 \\
(0.073)\end{array}$ & 0.000 & $\begin{array}{l}0.108 \\
(0.066)\end{array}$ & $\begin{array}{l}0.103 \\
(0.079)\end{array}$ & 0.001 \\
\hline Liquidity & $\begin{array}{l}0.140 \\
(0.267)\end{array}$ & $\begin{array}{l}0.205 \\
(0.265)\end{array}$ & $\begin{array}{l}0.086 \\
(0.258)\end{array}$ & 0.000 & $\begin{array}{l}0.186 \\
(0.286)\end{array}$ & $\begin{array}{l}0.124 \\
(0.259)\end{array}$ & 0.000 & $\begin{array}{l}0.161 \\
(0.245)\end{array}$ & $\begin{array}{l}0.111 \\
(0.292)\end{array}$ & 0.000 \\
\hline Coverage ratio & $\begin{array}{l}0.147 \\
(0.311)\end{array}$ & $\begin{array}{l}0.205 \\
(0.362)\end{array}$ & $\begin{array}{l}0.100 \\
(0.253)\end{array}$ & 0.000 & $\begin{array}{l}0.154 \\
(0.353)\end{array}$ & $\begin{array}{l}0.145 \\
(0.297)\end{array}$ & 0.134 & $\begin{array}{l}0.153 \\
(0.291)\end{array}$ & $\begin{array}{l}0.139 \\
(0.337)\end{array}$ & 0.018 \\
\hline Number of observations & 12,618 & $\begin{array}{l}5672 \\
(45.0 \%)\end{array}$ & $\begin{array}{l}6946 \\
(55.0 \%)\end{array}$ & & $\begin{array}{l}3132 \\
(24.8 \%)\end{array}$ & $\begin{array}{l}9486 \\
(75.2 \%)\end{array}$ & & $\begin{array}{l}7246 \\
(57.4 \%)\end{array}$ & $\begin{array}{l}5372 \\
(42.6 \%)\end{array}$ & \\
\hline
\end{tabular}

Notes: The table reports sample means. Standard deviations are presented in parentheses. $1 \%$ tails of the distribution of each variable in the table have been winsorised. Leverage is firms' total liability to total assets ratio; new equity, firms' ratio of (changes in total shareholder's equity - changes in retained earnings)/total assets; long-term debt, firms' outstanding long-term debt to total assets ratio; long-term debt dummy equals 1 if firm i has positive long-term debt in year t, and 0 otherwise; logtfp, logarithm of firm's total factor productivity; loglp, logarithm of real sales per employee; logS, logarithm of real sales; asset growth, the difference of logarithms of firms' real net fixed assets from time $t-1$ to $t$; tangibility, total tangible assets/total assets; ROA, firm's return on assets $=$ net profit/total assets; depreciation, depreciation/total assets; labour intensity = total wage bill/sales; liquidity, (current assets - current liabilities)/total assets; coverage ratio, net profit to current liabilities ratio. LP, Wooldridge GMM and ACF are the Levinsohn and Petrin (2003), the Wooldridge (2009) and the Ackerberg et al. (2015) methods of estimating TFP respectively. The currency unit is RMB yuan (the average exchange rate was approximately of USD: RMB = 1:6.3). See the Appendix for precise definitions of all variables. Diff. reports the p-values of the $t$-test statistics for the equality of means. Private firms are defined according to firms' ultimate controlling shareholders. A firm is defined as small and young if its real sales is ranked in the bottom 50 percentile of the real sales distribution of all firms in the same 2-digit industry and in the same year, and if its age is ranked in the bottom 50 percentile of the age distribution of all firms in the same 2-digit industry. Firm is defined an exporter if it has positive overseas sales in year $t$.

consistent with the pecking order theory, which suggests that under information asymmetries due to the higher costs and uncertainty of long-term finance, only high quality firms may be able to obtain external long-term finance. Private firms' liquidity and coverage ratio are more than double of those of others, which might show a better financial position of private firms. However, in the meanwhile they could also indicate precautionary internal finance buffer possibly because private firms are unable to secure external finance when they need. Overall, private firms seem to perform better and financially heathier, even though they seem to be disadvantaged in obtaining external borrowing. Perhaps due to their high labour intensity, private firms' labour productivity is only marginally higher than others'.

Column 5 to 7 compare small young firm-years with the rest. Small young firm-years take up about $24.8 \%$ of all firm-years. They are much lower in all three measures of external finance. Only a small proportion of them have long-term debt. They are also significantly less productive by all measures of TFP and labour productivity. Their asset growth is similar with others. They are much less profitable, have lower depreciation and are more labour intensive. Considering their lower external finance even with higher tangibility, we may suspect that small young firms do have difficulty in obtaining external finance. Small young firms are significantly more liquid, though their coverage ratio is similar with other firms. High liquidity could mean a good internal financial position, but on the other hand, it could also be a result of inability of obtaining external finance and consequently indicates more reliance of internal finance, especially when these firms also have lower performance indicators. Overall, small young firms seem to have worse quality than others. This important observation may suggest that the information asymmetry problem may be well at work among China's listed manufacturing firms, where small young firms suffer more. We try to explore whether conventional proxies for information asymmetries, i.e. firm size and age, would make a difference for the effects of firm productivity in helping raising external finance.

We also divide our sample firm-years according to whether firms 
export to overseas markets in a particular year. ${ }^{12} 57.4 \%$ of our sample firm-years export and $42.6 \%$ do not. All of our indicators are significantly different between exporters and non-exporters. Exporters have higher leverage and long-term debt, but lower new equity. There are a bigger proportion of exporters having positive long-term debt than non-exporters. Exporters are generally more productive than non-exporters by three out of four measures of productivity. Their sales size is larger, asset growth almost double of the non-exporters, and their profitability much higher. Exporters are less tangible on average. Their depreciation is only slightly higher. They also have much higher liquidity and coverage ratio. Overall, exporting manufacturing firms in our sample seem to have better quality, and with better internal financial position, they seem to rely more on equity finance, but do not seem to use more borrowing.

Generally, the descriptive statistics provide some preliminary evidence that higher productivity tend to be associated with higher equity finance, but not necessarily with higher leverage or long-term debt. The characteristics of firm ownership, size and age, export status all play a role in influencing firms' performance and finance. We also notice that in our sample high growth firms tend to have less long-term debt, which is in line with Barclay and Smith's (1995) finding that high growth firms prefer to use short-term debt.

\section{Results}

In this section, we provide a more detailed analysis of the link between productivity and external finance, and the extent to which the characteristics of firm ownership, size and age, and export status affect the sensitivity of three forms of external finance, i.e. total leverage, new equity and long-term debt, to productivity, i.e. three measures of TFP as well as labour productivity.

\subsection{Productivity effects on firms' total leverage}

First, in column 1 to 3 of Table 2 we estimate Eq. (1) with three measures of TFP and total leverage and show the results for the full sample. Only Wooldridge TFP has a significant positive effect on firms' total leverage. In column 4 of Table 2 we show the full sample results using labour productivity, which has no effect on firms' leverage. Labour productivity does not measure other aspects of firms' efficiency than the labour input, but it can be easily measured and readily available to external finance providers. However, the simple measurement of labour productivity may bias towards capital-intensive firms. Especially the Chinese export sector is dominated by labour intensive industries, which are better at producing labour intensive goods than non-exporters, but they might not be efficient in terms of other aspects of production. Therefore, to account for the possible differences of labour intensity when examining the effect of labour productivity, we add a ratio of firms' total wage bill to sales to the labour productivity regressions.

To further eliminate potential influence of firms' ownerships, we produce the above regressions on private firm sample and report the results in column 5 to 8 in Table 2. Only the Wooldridge and ACF TFP have significant positive effects on leverage, and it is evident that these results are not subject to firms' ownership influence.

Other variables are all reasonable and remarkably consistent between the whole and private samples. The lagged leverage variable has a large positive and significant coefficient suggesting an obvious dynamic behaviour. The effect of firm size is not totally clear as suggested

\footnotetext{
${ }^{12}$ Some of our sample firms do switch between exporters and non-exporters, but it is extremely rare that they changed frequently or dramatically in terms of export sales during the sample period. In order to capture particularly firms' switch from non-exporter to exporter, which is likely due to productivity improvement according to Melitz (2003), we define firms' export status by year.
}

by different regressions. While large firms may be able to borrow more since they are less likely to suffer from information asymmetry problems, they may also be more self-sufficient and rely less on external borrowing. Fixed asset growth has negative significant effects on leverage, which is consistent with the prediction of agency theory, where high growth firms prefer to reduce leverage to control for agency cost associated with managers' misbehaviour arising from the growth opportunities (Jensen \& Meckling, 1976). Tangibility also plays a significant positive role in determining leverage, as tangible assets could serve as collateral for external finance. Profitability has a negative but insignificant effect. Depreciation ratio, to control the possibility that firms may depreciate their assets to shield off some tax instead of using debt for the same purpose, also reduces leverage as expected.

$\mathrm{m} 3$ and Hansen tests show that all of our system GMM regressions are appropriate. Overall, we find some positive effects of productivity on firms' leverage. To further verify the robustness of this result, we also use the change of total leverage, current leverage and short-term debt ratio as the dependent variables. Since an increase in total leverage could be due to an increase in total liabilities or a decrease in total assets, using total leverage as a measure may not correctly capture firms' borrowing behaviour. Therefore, we also use the change of total liabilities over total assets ratio, and the results in Table A4 is remarkably consistent with Table 2. Results in Tables A5 and A6 also show that productivity has little effect in helping firms with short-term borrowing. This is reasonable, as short-term lenders might not worry about firms' long-term performance like productivity, instead they would care more about firms' ability in repaying the debts in the short term like some balance sheet indicators.

\subsection{Productivity effects on firms' new issue of equity}

Though equity finance may be less favoured than debt finance by firms since issuing new equity is more costly according to the pecking order theory, our sample firms on average have a total shareholders' equity to total assets ratio of 0.413 , whereas their average total outstanding long-term debt to total assets ratio is only 0.054 . As shown in Table 1 new issue of equity ratio is higher than long-term debt ratio for every category of firms. It seems that equity finance is a highly important form of external finance for Chinese listed firms. Therefore, it is vital for us to explore how productivity affects different types of external finance.

In Table 3 we find highly significant and positive productivity effects for firms' new equity in all the regressions, suggesting high productivity helps firms to raise more equity finance. Comparing with Table 2, the coefficients of some of the control variables have opposite signs, i.e. the lagged new equity variable, ROA and depreciation ratio, but are still all reasonable. The lagged new equity variable is negative and significant in all the regressions, which suggests a correction behaviour of firms' new equity issues, as firms often wish to maintain a smooth stream of new equity issuance (Bolton, Chen, \& Wang, 2013). Comparing with Table 2, ROA has a positive effect instead, which is sensible. High profit could be a substitute for debt, but more attractive to investors and makes issuing new equity easy. Depreciation is positive and significant as expected, opposite its signs in the leverage regressions in Table 2. While depreciation is an alternative tax shield substituting for debt, it reduces retained earnings and induces firms to issue equity. Again, the private firm sample has highly consistent results with the whole sample, and all the tests show our regressions are appropriate. We seem to find strong evidence that equity finance goes to the more productive firms.

\subsection{Productivity effects on firms' long-term debt}

We then further explore the effect of productivity on another major form of external finance, long-term debt, which is defined as firms' borrowing from banks or other financial institutions with a maturity 
Table 2

The effect of productivity on total leverage.

\begin{tabular}{|c|c|c|c|c|c|c|c|c|}
\hline \multirow[t]{3}{*}{${\text { Dependent variable: } \text { leverage }_{i t}}$} & \multicolumn{4}{|l|}{ All } & \multicolumn{4}{|l|}{ Private } \\
\hline & LP & Wooldridge & $\mathrm{ACF}$ & Labour productivity & LP & Wooldridge & $\mathrm{ACF}$ & Labour productivity \\
\hline & (1) & $(2)$ & (3) & (4) & (5) & (6) & (7) & (8) \\
\hline leverage $_{i, t-1}$ & $\begin{array}{l}0.685^{* * * *} \\
(0.040)\end{array}$ & $\begin{array}{l}0.664^{* * *} \\
(0.039)\end{array}$ & $\begin{array}{l}0.658^{* * *} \\
(0.040)\end{array}$ & $\begin{array}{l}0.646^{* * * *} \\
(0.041)\end{array}$ & $\begin{array}{l}0.785^{\text {***** }} \\
(0.054)\end{array}$ & $\begin{array}{l}0.750^{* * * *} \\
(0.057)\end{array}$ & $\begin{array}{l}0.647^{\text {**** }} \\
(0.049)\end{array}$ & $\begin{array}{l}0.730^{* * * *} \\
(0.053)\end{array}$ \\
\hline $\log S_{i t-1}$ & $\begin{array}{l}0.015^{*} \\
(0.007)\end{array}$ & $\begin{array}{l}-0.051^{* *} \\
(0.021)\end{array}$ & $\begin{array}{l}-0.002 \\
(0.009)\end{array}$ & $\begin{array}{l}0.027^{* * *} \\
(0.008)\end{array}$ & $\begin{array}{l}0.005 \\
(0.012)\end{array}$ & $\begin{array}{l}-0.076^{* * *} \\
(0.032)\end{array}$ & $\begin{array}{l}-0.019 \\
(0.012)\end{array}$ & $\begin{array}{l}0.009 \\
(0.016)\end{array}$ \\
\hline asset growth ${ }_{\text {it- } 1}$ & $\begin{array}{l}-0.187^{\text {**** }} \\
(0.031)\end{array}$ & $\begin{array}{l}-0.206^{* * *} \\
(0.030)\end{array}$ & $\begin{array}{l}-0.214^{* * * *} \\
(0.031)\end{array}$ & $\begin{array}{l}-0.196^{* * * *} \\
(0.030)\end{array}$ & $\begin{array}{l}-0.239^{* * *} \\
(0.046)\end{array}$ & $\begin{array}{l}-0.262^{* * *} \\
(0.045)\end{array}$ & $\begin{array}{l}-0.211^{* * *} \\
(0.031)\end{array}$ & $\begin{array}{l}-0.217^{* * *} \\
(0.045)\end{array}$ \\
\hline tangibility $_{\mathrm{it}-1}$ & $\begin{array}{l}0.493^{* * *} \\
(0.116)\end{array}$ & $\begin{array}{l}0.622^{* * * *} \\
(0.124)\end{array}$ & $\begin{array}{l}0.591^{* * *} \\
(0.136)\end{array}$ & $\begin{array}{l}0.524^{* * * *} \\
(0.116)\end{array}$ & $\begin{array}{l}0.574^{* * * *} \\
(0.200)\end{array}$ & $\begin{array}{l}0.699^{* * * *} \\
(0.201)\end{array}$ & $\begin{array}{l}0.702^{* * * *} \\
(0.193)\end{array}$ & $\begin{array}{l}0.629^{* * *} \\
(0.186)\end{array}$ \\
\hline roa $_{\text {it-1 }}$ & $\begin{array}{l}-0.047 \\
(0.210)\end{array}$ & $\begin{array}{l}-0.281 \\
(0.176)\end{array}$ & $\begin{array}{l}-0.186 \\
(0.176)\end{array}$ & $\begin{array}{l}0.050 \\
(0.170)\end{array}$ & $\begin{array}{l}-0.241 \\
(0.320)\end{array}$ & $\begin{array}{l}-0.392 \\
(0.294)\end{array}$ & $\begin{array}{l}-0.251 \\
(0.219)\end{array}$ & $\begin{array}{l}0.041 \\
(0.274)\end{array}$ \\
\hline $\operatorname{dep}_{\text {it- } 1}$ & $\begin{array}{l}-5.855^{* * *} \\
(0.988)\end{array}$ & $\begin{array}{l}-5.540^{* * * *} \\
(1.005)\end{array}$ & $\begin{array}{l}-5.629^{* * *} \\
(0.965)\end{array}$ & $\begin{array}{l}-5.841^{\text {***** }} \\
(0.991)\end{array}$ & $\begin{array}{l}-7.520^{* * *} \\
(2.128)\end{array}$ & $\begin{array}{l}-7.861^{\text {**** }} \\
(2.219)\end{array}$ & $\begin{array}{l}-5.985^{* * * *} \\
(1.447)\end{array}$ & $\begin{array}{l}-7.548^{\text {**** }} \\
(1.981)\end{array}$ \\
\hline $\operatorname{logtf} \mathrm{p}_{\mathrm{it}-1}$ & $\begin{array}{c}-0.021 \\
(0.072)\end{array}$ & $\begin{array}{l}1.734^{* * *} \\
(0.627)\end{array}$ & $\begin{array}{l}0.340 \\
(0.228)\end{array}$ & & $\begin{array}{l}0.069 \\
(0.083)\end{array}$ & $\begin{array}{l}2.156^{* * *} \\
(0.924)\end{array}$ & $\begin{array}{l}0.506^{*} \\
(0.275)\end{array}$ & \\
\hline labour intensity ${ }_{\mathrm{it}-1}$ & & & & $\begin{array}{l}0.488^{* *} \\
(0.224)\end{array}$ & & & & $\begin{array}{l}0.310 \\
(0.371)\end{array}$ \\
\hline $\log \mathrm{p}_{\mathrm{it}-1}$ & & & & $\begin{array}{l}-0.009 \\
(0.015)\end{array}$ & & & & $\begin{array}{l}0.000 \\
(0.027)\end{array}$ \\
\hline m3 (p-value) & 0.240 & 0.287 & 0.272 & 0.208 & 0.645 & 0.609 & 0.683 & 0.684 \\
\hline $\mathrm{J}$ (Hansen) & 0.144 & 0.140 & 0.163 & 0.185 & 0.509 & 0.534 & 0.983 & 0.191 \\
\hline IVs (lags) & $\mathrm{t}-3, \ldots$ & $\mathrm{t}-3, \ldots$ & $\mathrm{t}-3, \ldots$ & $\mathrm{t}-3, \ldots$ & $\mathrm{t}-3, \ldots$ & $\mathrm{t}-3, \ldots$ & $\mathrm{t}-3, \ldots$ & $\mathrm{t}-3, \ldots$ \\
\hline & $\Delta \mathrm{t}-2 \ldots$ & $\Delta \mathrm{t}-2 \ldots$ & $\Delta \mathrm{t}-2 \ldots$ & $\Delta \mathrm{t}-2 \ldots$ & $\Delta \mathrm{t}-2 \ldots$ & $\Delta \mathrm{t}-2 \ldots$ & $\Delta \mathrm{t}-2 \ldots$ & $\Delta \mathrm{t}-2 \ldots$ \\
\hline number of observations & 12,618 & 12,623 & 12,623 & 12,624 & 5672 & 5674 & 5674 & 5676 \\
\hline
\end{tabular}

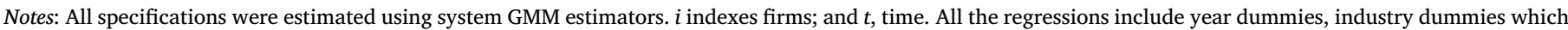






significance at the $5 \%$ level. ${ }^{* * *}$ indicates significance at the $1 \%$ level. Also see Notes to Table 1 .

Table 3

The effect of productivity on new equity.

\begin{tabular}{|c|c|c|c|c|c|c|c|c|}
\hline \multirow[t]{3}{*}{ Dependent variable: new equity ${ }_{i t}$} & \multicolumn{4}{|l|}{ All } & \multicolumn{4}{|l|}{ Private } \\
\hline & LP & Wooldridge & ACF & Labour productivity & LP & Wooldridge & $\mathrm{ACF}$ & Labour productivity \\
\hline & (1) & (2) & (3) & (4) & (5) & (6) & (7) & $(8)$ \\
\hline new equity ${ }_{i, t-1}$ & $\begin{array}{l}-0.086^{* *} \\
(0.036)\end{array}$ & $\begin{array}{l}-0.023 \\
(0.069)\end{array}$ & $\begin{array}{l}-0.109^{* * *} \\
(0.042)\end{array}$ & $\begin{array}{l}-0.050 \\
(0.040)\end{array}$ & $\begin{array}{l}-0.080^{*} \\
(0.046)\end{array}$ & $\begin{array}{l}-0.134^{* * *} \\
(0.051)\end{array}$ & $\begin{array}{l}0.126 \\
(0.084)\end{array}$ & $\begin{array}{l}0.050 \\
(0.056)\end{array}$ \\
\hline $\log S_{\text {it- } 1}$ & $\begin{array}{l}-0.022^{* * *} \\
(0.007)\end{array}$ & $\begin{array}{l}-0.116^{* * *} \\
(0.030)\end{array}$ & $\begin{array}{l}-0.075^{* * *} \\
(0.011)\end{array}$ & $\begin{array}{l}-0.042^{* * *} \\
(0.008)\end{array}$ & $\begin{array}{l}-0.037^{\text {***** }} \\
(0.010)\end{array}$ & $\begin{array}{l}-0.154^{* * * *} \\
(0.041)\end{array}$ & $\begin{array}{l}-0.079^{* * * *} \\
(0.016)\end{array}$ & $\begin{array}{l}-0.043^{* * * *} \\
(0.014)\end{array}$ \\
\hline asset growth ${ }_{\text {it-1 }}$ & $\begin{array}{l}-0.042^{*} \\
(0.023)\end{array}$ & $\begin{array}{l}-0.069^{*} \\
(0.036)\end{array}$ & $\begin{array}{c}-0.012 \\
(0.027)\end{array}$ & $\begin{array}{l}-0.060^{* *} \\
(0.024)\end{array}$ & $\begin{array}{l}-0.047^{*} \\
(0.025)\end{array}$ & $\begin{array}{l}-0.016 \\
(0.033)\end{array}$ & $\begin{array}{l}-0.151^{* * *} \\
(0.046)\end{array}$ & $\begin{array}{l}-0.083^{* *} \\
(0.033)\end{array}$ \\
\hline tangibility ${ }_{\text {it- } 1}$ & $\begin{array}{l}0.068 \\
(0.098)\end{array}$ & $\begin{array}{l}0.375^{*} \\
(0.194)\end{array}$ & $\begin{array}{l}0.345^{* * * *} \\
(0.132)\end{array}$ & $\begin{array}{l}-0.049 \\
(0.109)\end{array}$ & $\begin{array}{l}0.184 \\
(0.172)\end{array}$ & $\begin{array}{l}-0.101 \\
(0.261)\end{array}$ & $\begin{array}{l}0.763^{* * * *} \\
(0.290)\end{array}$ & $\begin{array}{l}0.330 \\
(0.203)\end{array}$ \\
\hline roa $_{\text {it-1 }}$ & $\begin{array}{l}0.113 \\
(0.181)\end{array}$ & $\begin{array}{l}0.730^{* * * *} \\
(0.260)\end{array}$ & $\begin{array}{l}0.357^{*} \\
(0.190)\end{array}$ & $\begin{array}{l}0.163 \\
(0.172)\end{array}$ & $\begin{array}{l}0.170 \\
(0.199)\end{array}$ & $\begin{array}{l}0.188 \\
(0.239)\end{array}$ & $\begin{array}{l}0.807^{* * *} \\
(0.315)\end{array}$ & $\begin{array}{l}0.347 \\
(0.271)\end{array}$ \\
\hline $\operatorname{dep}_{\text {it-1 }}$ & $\begin{array}{l}1.412^{*} \\
(0.855)\end{array}$ & $\begin{array}{l}-0.370 \\
(1.719)\end{array}$ & $\begin{array}{l}1.448 \\
(0.933)\end{array}$ & $\begin{array}{l}2.387^{* * * *} \\
(0.908)\end{array}$ & $\begin{array}{l}1.405 \\
(1.580)\end{array}$ & $\begin{array}{l}3.742^{*} \\
(1.965)\end{array}$ & $\begin{array}{l}-2.938 \\
(2.358)\end{array}$ & $\begin{array}{l}-0.810 \\
(1.841)\end{array}$ \\
\hline $\operatorname{logtfp_{it-1}}$ & $\begin{array}{l}0.143^{* *} \\
(0.057)\end{array}$ & $\begin{array}{l}2.459^{* * *} \\
(0.864)\end{array}$ & $\begin{array}{l}1.102^{* * *} \\
(0.226)\end{array}$ & & $\begin{array}{l}0.202^{* * *} \\
(0.074)\end{array}$ & $\begin{array}{l}3.118^{* * *} \\
(1.029)\end{array}$ & $\begin{array}{l}0.823^{* * * *} \\
(0.298)\end{array}$ & \\
\hline labour intensity it-1 $_{1}$ & & & & $\begin{array}{l}0.012 \\
(0.209)\end{array}$ & & & & $\begin{array}{l}0.406 \\
(0.345)\end{array}$ \\
\hline $\log l p_{i t-1}$ & & & & $\begin{array}{l}0.050^{* * *} \\
(0.014)\end{array}$ & & & & $\begin{array}{l}0.053^{* * *} \\
(0.019)\end{array}$ \\
\hline m2 (p-value) & 0.611 & & & 0.430 & 0.401 & & & 0.511 \\
\hline m3 (p-value) & & 0.690 & 0.849 & & & & 0.781 & \\
\hline m4 (p-value) & & & & & & 0.917 & & \\
\hline $\mathrm{J}$ (Hansen) & 0.158 & 0.112 & 0.063 & 0.217 & 0.153 & 0.527 & 0.261 & 0.210 \\
\hline IVs (lags) & $\mathrm{t}-2, \ldots$ & $\mathrm{t}-3, \ldots$ & $\mathrm{t}-3, \ldots$ & $\mathrm{t}-2, \ldots$ & $\mathrm{t}-2, \ldots$ & $\mathrm{t}-4, \ldots$ & $\mathrm{t}-2, \ldots$ & $\mathrm{t}-2, \ldots$ \\
\hline & $\Delta \mathrm{t}-1 \ldots$ & $\Delta \mathrm{t}-2 \ldots$ & $\Delta \mathrm{t}-2 \ldots$ & $\Delta \mathrm{t}-1 \ldots$ & $\Delta \mathrm{t}-1 \ldots$ & $\Delta \mathrm{t}-3 \ldots$ & $\Delta \mathrm{t}-1 \ldots$ & $\Delta \mathrm{t}-1 \ldots$ \\
\hline number of observations & 12,611 & 12,616 & 12,616 & 12,617 & 5672 & 5674 & 5674 & 5676 \\
\hline
\end{tabular}

Notes: see notes to Tables 1 and 2 . 
Table 4

The effect of productivity on long-term debt.

\begin{tabular}{|c|c|c|c|c|c|c|c|c|}
\hline \multirow[t]{3}{*}{ Dependent variable: $\operatorname{ltd}_{\mathrm{it}}$} & \multicolumn{4}{|l|}{ All } & \multicolumn{4}{|l|}{ Private } \\
\hline & LP & Wooldridge & $\mathrm{ACF}$ & Labour productivity & LP & Wooldridge & ACF & Labour productivity \\
\hline & (1) & (2) & (3) & (4) & (5) & (6) & (7) & (8) \\
\hline $\operatorname{ltd}_{\mathrm{i}, \mathrm{t}-1}$ & $\begin{array}{l}0.689^{* * * *} \\
(0.029)\end{array}$ & $\begin{array}{l}0.814^{* * *} \\
(0.038)\end{array}$ & $\begin{array}{l}0.821^{* * * *} \\
(0.040)\end{array}$ & $\begin{array}{l}0.675^{\text {**** }} \\
(0.027)\end{array}$ & $\begin{array}{l}0.602^{* * * *} \\
(0.050)\end{array}$ & $\begin{array}{l}0.631^{\text {**** }} \\
(0.051)\end{array}$ & $\begin{array}{l}0.551^{\text {**** }} \\
(0.039)\end{array}$ & $\begin{array}{l}0.527^{* * *} \\
(0.041)\end{array}$ \\
\hline $\log S_{i t-1}$ & $\begin{array}{l}-0.001 \\
(0.002)\end{array}$ & $\begin{array}{l}0.005 \\
(0.011)\end{array}$ & $\begin{array}{l}-0.004 \\
(0.003)\end{array}$ & $\begin{array}{l}-4.57 \mathrm{e}-3 \\
(0.002)\end{array}$ & $\begin{array}{l}0.007^{* * *} \\
(0.003)\end{array}$ & $\begin{array}{l}0.016 \\
(0.011)\end{array}$ & $\begin{array}{l}0.003 \\
(0.003)\end{array}$ & $\begin{array}{l}0.005 \\
(0.003)\end{array}$ \\
\hline asset growth $\mathrm{it-1}_{1}$ & $\begin{array}{l}-0.013 \\
(0.008)\end{array}$ & $\begin{array}{l}-0.014 \\
(0.012)\end{array}$ & $\begin{array}{l}-0.016 \\
(0.013)\end{array}$ & $\begin{array}{l}-0.012 \\
(0.008)\end{array}$ & $\begin{array}{l}-0.028^{* * *} \\
(0.010)\end{array}$ & $\begin{array}{l}-0.016 \\
(0.010)\end{array}$ & $\begin{array}{l}-0.021^{* * * *} \\
(0.006)\end{array}$ & $\begin{array}{l}-0.022^{* * *} \\
(0.007)\end{array}$ \\
\hline tangibility $_{\text {it-1 }}$ & $\begin{array}{l}0.076^{* *} \\
(0.030)\end{array}$ & $\begin{array}{l}0.017 \\
(0.057)\end{array}$ & $\begin{array}{l}0.031 \\
(0.056)\end{array}$ & $\begin{array}{l}0.071^{* * *} \\
(0.029)\end{array}$ & $\begin{array}{l}0.089^{* *} \\
(0.038)\end{array}$ & $\begin{array}{l}0.041 \\
(0.050)\end{array}$ & $\begin{array}{l}0.100^{* * *} \\
(0.043)\end{array}$ & $\begin{array}{l}0.097^{* * * *} \\
(0.032)\end{array}$ \\
\hline roa $_{\text {it-1 }}$ & $\begin{array}{l}0.129^{* *} \\
(0.056)\end{array}$ & $\begin{array}{l}0.205^{* * *} \\
(0.077)\end{array}$ & $\begin{array}{l}0.200^{* *} \\
(0.077)\end{array}$ & $\begin{array}{l}0.144^{* *} \\
(0.051)\end{array}$ & $\begin{array}{l}0.050 \\
(0.061)\end{array}$ & $\begin{array}{l}0.024 \\
(0.069)\end{array}$ & $\begin{array}{l}0.044 \\
(0.045)\end{array}$ & $\begin{array}{l}0.087^{*} \\
(0.046)\end{array}$ \\
\hline $\operatorname{dep}_{\text {it-1 }}$ & $\begin{array}{l}-0.511^{* *} \\
(0.215)\end{array}$ & $\begin{array}{l}-0.033 \\
(0.405)\end{array}$ & $\begin{array}{l}-0.041 \\
(0.398)\end{array}$ & $\begin{array}{l}-0.454^{* *} \\
(0.226)\end{array}$ & $\begin{array}{l}-1.391^{* * *} \\
(0.391)\end{array}$ & $\begin{array}{l}-0.774^{* *} \\
(0.403)\end{array}$ & $\begin{array}{l}-1.182^{* * *} \\
(0.308)\end{array}$ & $\begin{array}{l}-1.285^{* * * *} \\
(0.292)\end{array}$ \\
\hline $\log t f p_{i t-1}$ & $\begin{array}{l}0.032^{*} \\
(0.018)\end{array}$ & $\begin{array}{l}-0.131 \\
(0.206)\end{array}$ & $\begin{array}{l}0.094 \\
(0.073)\end{array}$ & & $\begin{array}{l}0.019 \\
(0.021)\end{array}$ & $\begin{array}{l}-0.244 \\
(0.219)\end{array}$ & $\begin{array}{l}0.122^{*} \\
(0.066)\end{array}$ & \\
\hline labour intensity ${ }_{i t-1}$ & & & & $\begin{array}{l}0.156^{\text {**** }} \\
(0.058)\end{array}$ & & & & $\begin{array}{l}0.068 \\
(0.060)\end{array}$ \\
\hline $\log l p_{i t-1}$ & & & & $\begin{array}{l}0.012^{* * *} \\
(0.004)\end{array}$ & & & & $\begin{array}{l}0.009^{* *} \\
(0.04)\end{array}$ \\
\hline m2 (p-value) & & & & & 0.762 & 0.410 & 0.725 & 0.814 \\
\hline m3 (p-value) & 0.257 & 0.194 & 0.197 & 0.241 & & & & \\
\hline J (Hansen) & 0.391 & 0.327 & 0.265 & 0.251 & 0.475 & 0.538 & 0.157 & 0.739 \\
\hline IVs (lags) & $\begin{array}{l}\mathrm{t}-3, \ldots \\
\Delta \mathrm{t}-2 \ldots\end{array}$ & $\begin{array}{l}\mathrm{t}-3, \ldots \\
\Delta \mathrm{t}-2 \ldots\end{array}$ & $\begin{array}{l}\mathrm{t}-3, \ldots \\
\Delta \mathrm{t}-2 \ldots\end{array}$ & $\begin{array}{l}\mathrm{t}-3, \ldots \\
\Delta \mathrm{t}-2 \ldots\end{array}$ & $\begin{array}{l}\mathrm{t}-2, \ldots \\
\Delta \mathrm{t}-1 \ldots\end{array}$ & $\begin{array}{l}\mathrm{t}-2, \ldots \\
\Delta \mathrm{t}-1 \ldots\end{array}$ & $\begin{array}{l}\mathrm{t}-2, \ldots \\
\Delta \mathrm{t}-1 \ldots\end{array}$ & $\begin{array}{l}\mathrm{t}-2, \ldots \\
\Delta \mathrm{t}-1 \ldots\end{array}$ \\
\hline number of observations & 12,402 & 12,407 & 12,407 & 12,408 & 5564 & 5566 & 5566 & 5568 \\
\hline
\end{tabular}

Notes: see notes to Tables 1 and 2.

over a year. Such long-term debt would be costly for firms to obtain. Figures in Table 1 show that our sample firms' long-term debt is only about $10 \%$ of their total liabilities ${ }^{13}$ on average for all categories of firms. On the other hand, short-term finance such as trade credit and overdraft credit lines would be relatively easy to get and do not necessarily involves borrowers' particular effort for each borrowing. Thus, it is important to check firms' long-term debt without the influence of other forms of more easily accessible short-term finance.

Table 4 shows the effects of productivity on firms' long-term debt. Only LP TFP and labour productivity models for the whole sample, and ACF TFP and labour productivity models for the private sample show positive significant productivity effects. All other control variables show sensible and consistent results in both samples. All the tests suggest our regression models are appropriate. Overall, our results suggest that productivity helps firms to raise long-term debt to some extent, but the effect is not as strong as the one on firms' new equity finance.

In general, we find that productivity does help firms to raise external finance, especially new equity finance, but the effect is slightly weaker on leverage and long-term debt. To check more robustness of our results, we also use the three-year moving average of all the four measures of productivity as our dependent variables, so that our results are more independent from the volatility of productivity, i.e. less influenced by the predictability of past productivity for future productivity. As showed in Tables A7, A8 and A9 the productivity effects are consistent and even much stronger.

\subsection{Does the productivity effect vary?}

Now we try to explore in more details whether the productivity and external finance nexus differ along some dimensions of firm

\footnotetext{
${ }^{13}$ We use the long-term debt ratio in the 3rd row of Table 1 to divide the leverage in the 1st row to calculate the relative size of long-term debt to total liabilities.
}

characteristics. First, we split our sample firms by their size and age together. Firms, which are in the lower half of the distribution of both real sales and age of all the firms in the same year and same industry, are classified as small young firms. ${ }^{14}$ Small young firms in our sample indeed have less external finance, and lower values in performance indicators than others as shown in Table 1.

Then we also split our sample into exporters and non-exporter. Many foreign invested manufacturing firms in low labour cost countries are established with the sole purpose of exporting their products back to foreign markets, which suggest that these firms do not have to bear the sunk cost of export and may not necessarily have better quality than their domestic counterparts. However, we do not have such concern, since $95.75 \%$ of our sample firms are domestic firms, ${ }^{15}$ i.e. exporters in our sample are most likely to be the genuine productive exporters as Melitz (2003) models. Figures in Table 1 show that exporters and nonexporters are highly distinctive from each other, and exporters do seem to have better performance.

Table 5 presents the results of Eq. (2). Big and/or old firms have a positive significant productivity effect on their leverage only by the Wooldridge TFP regression in column 2, where large and/or old firms have a significantly higher TFP effects on their leverage than small young firms as shown by the significant $\chi^{2}$ statistics. Exporters show some marginally higher positive significant TFP effects on leverage than non-exporters by the Wooldridge and ACF TFP regressions in column 6 and 7. These results are much in line with the whole sample results in Table 2. Labour productivity has no effect on leverage for any of the firm groups. All the tests show that our regressions are reasonable, and control variables are all sensible too. Overall, we see some weak evidence that it is the better quality firm groups being able to utilise TFP to increase leverage, and labour productivity does not seem to help.

\footnotetext{
${ }^{14}$ Firms' size and age effects are related to the nature of the industry, business cycle, life cycle of the industry etc. Therefore, we take into account of industry and year when defining firms to be small and young.

${ }^{15}$ More details of the ownership structure of our sample firm-years can be found in Table A3 in the Appendix.
} 
Table 5

The effect of productivity on total leverage.

\begin{tabular}{|c|c|c|c|c|c|c|c|c|}
\hline \multirow[t]{3}{*}{ Dependent variable: leverage $_{i t}$} & \multicolumn{4}{|c|}{ Small \& young/others } & \multicolumn{4}{|c|}{ Exporters/non-exporters } \\
\hline & LP & Wooldridge & ACF & Labour productivity & LP & Wooldridge & ACF & Labour productivity \\
\hline & (1) & (2) & (3) & (4) & (5) & (6) & (7) & (8) \\
\hline leverage $_{\mathrm{i}, \mathrm{t}-1}$ & $\begin{array}{l}0.691^{* * *} \\
(0.042)\end{array}$ & $\begin{array}{l}0.645^{* * *} \\
(0.040)\end{array}$ & $\begin{array}{l}0.639^{* * *} \\
(0.041)\end{array}$ & $\begin{array}{l}0.645^{* * * *} \\
(0.042)\end{array}$ & $\begin{array}{l}0.667^{* * * *} \\
(0.043)\end{array}$ & $\begin{array}{l}0.644^{* * * *} \\
(0.043)\end{array}$ & $\begin{array}{l}0.642^{\text {**** }} \\
(0.043)\end{array}$ & $\begin{array}{l}0.679^{* * * *} \\
(0.045)\end{array}$ \\
\hline $\log S_{\text {it-1 }}$ & $\begin{array}{l}0.017^{* *} \\
(0.007)\end{array}$ & $\begin{array}{l}-0.039^{*} \\
(0.020)\end{array}$ & $\begin{array}{l}-0.000 \\
(0.009)\end{array}$ & $\begin{array}{l}0.026^{* * * *} \\
(0.008)\end{array}$ & $\begin{array}{l}0.022^{* *} \\
(0.008)\end{array}$ & $\begin{array}{l}-0.046^{*} \\
(0.024)\end{array}$ & $\begin{array}{l}-0.001 \\
(0.033)\end{array}$ & $\begin{array}{l}0.034^{* * * *} \\
(0.010)\end{array}$ \\
\hline asset growth ${ }_{\text {it- } 1}$ & $\begin{array}{l}-0.192^{* * * *} \\
(0.031)\end{array}$ & $\begin{array}{l}-0.204^{* * * *} \\
(0.027)\end{array}$ & $\begin{array}{l}-0.206^{* * * *} \\
(0.029)\end{array}$ & $\begin{array}{l}-0.199^{* * * *} \\
(0.030)\end{array}$ & $\begin{array}{l}-0.194^{* * *} \\
(0.032)\end{array}$ & $\begin{array}{l}-0.228^{* * *} \\
(0.032)\end{array}$ & $\begin{array}{l}-0.232^{* * *} \\
(0.033)\end{array}$ & $\begin{array}{l}-0.200^{* * *} \\
(0.036)\end{array}$ \\
\hline tangibility $_{\mathrm{it}-1}$ & $\begin{array}{l}0.493^{* *} \\
(0.120)\end{array}$ & $\begin{array}{l}0.622^{* * *} \\
(0.116)\end{array}$ & $\begin{array}{l}0.580^{* * * *} \\
(0.127)\end{array}$ & $\begin{array}{l}0.542^{* * * *} \\
(0.111)\end{array}$ & $\begin{array}{l}0.500^{* * * *} \\
(0.119)\end{array}$ & $\begin{array}{l}0.636^{* * * *} \\
(0.126)\end{array}$ & $\begin{array}{l}0.599^{* * * *} \\
(0.140)\end{array}$ & $\begin{array}{l}0.448^{* * *} \\
(0.119)\end{array}$ \\
\hline roa $_{\text {it-1 }}$ & $\begin{array}{l}-0.155^{* * *} \\
(0.215)\end{array}$ & $\begin{array}{l}-0.299^{*} \\
(0.162)\end{array}$ & $\begin{array}{c}-0.237 \\
(0.166)\end{array}$ & $\begin{array}{l}-0.003 \\
(0.162)\end{array}$ & $\begin{array}{l}-0.086 \\
(0.233)\end{array}$ & $\begin{array}{l}-0.320^{*} \\
(0.191)\end{array}$ & $\begin{array}{l}-0.280 \\
(0.196)\end{array}$ & $\begin{array}{l}-0.110 \\
(0.198)\end{array}$ \\
\hline dep $_{\text {it-1 }}$ & $\begin{array}{l}-6.058^{* * *} \\
(0.977)\end{array}$ & $\begin{array}{l}-5.715^{\text {**** }} \\
(0.965)\end{array}$ & $\begin{array}{l}-5.716^{* * *} \\
(0.924)\end{array}$ & $\begin{array}{l}-6.072^{* * *} \\
(0.928)\end{array}$ & $\begin{array}{l}-6.398^{* * * *} \\
(0.974)\end{array}$ & $\begin{array}{l}-6.298^{* * *} \\
(0.997)\end{array}$ & $\begin{array}{l}-6.223^{* * *} \\
(0.966)\end{array}$ & $\begin{array}{l}-5.962^{* * * *} \\
(1.019)\end{array}$ \\
\hline $\operatorname{logtfp}_{\text {it- } 1} \times$ type 1 & $\begin{array}{c}-0.027 \\
(0.076)\end{array}$ & $\begin{array}{l}1.351^{* *} \\
(0.606)\end{array}$ & $\begin{array}{l}0.209 \\
(0.214)\end{array}$ & & $\begin{array}{l}-0.013 \\
(0.081)\end{array}$ & $\begin{array}{l}1.770^{* * *} \\
(0.700)\end{array}$ & $\begin{array}{l}0.425^{*} \\
(0.242)\end{array}$ & \\
\hline $\operatorname{logtfp}_{\mathrm{it}-1} \times(1$-type1) & $\begin{array}{c}-0.004 \\
(0.073)\end{array}$ & $\begin{array}{l}1.362^{* *} \\
(0.604)\end{array}$ & $\begin{array}{l}0.228 \\
(0.212)\end{array}$ & & $\begin{array}{c}-0.027 \\
(0.076)\end{array}$ & $\begin{array}{l}1.759^{* *} \\
(0.699)\end{array}$ & $\begin{array}{l}0.413^{*} \\
(0.239)\end{array}$ & \\
\hline labour intensity ${ }_{\mathrm{it}-1}$ & & & & $\begin{array}{l}0.358 \\
(0.221)\end{array}$ & & & & $\begin{array}{l}-6.398^{* * * *} \\
(0.974)\end{array}$ \\
\hline $\operatorname{loglp}_{\text {it- } 1} \times$ type 1 & & & & $\begin{array}{l}-0.024 \\
(0.015)\end{array}$ & & & & $\begin{array}{l}-0.013 \\
(0.081)\end{array}$ \\
\hline $\operatorname{loglp}_{\text {it-1 }} \times(1$-type1) & & & & $\begin{array}{l}-0.020 \\
(0.015)\end{array}$ & & & & $\begin{array}{c}-0.027 \\
(0.076)\end{array}$ \\
\hline m3 (p-value) & 0.234 & 0.281 & 0.263 & 0.209 & 0.249 & 0.303 & 0.278 & 0.249 \\
\hline $\mathrm{J}$ (Hansen) & 0.141 & 0.126 & 0.178 & 0.097 & 0.196 & 0.222 & 0.259 & 0.196 \\
\hline IVs (lags) & $\mathrm{t}-3, \ldots$ & $\mathrm{t}-3, \ldots$ & $\mathrm{t}-3, \ldots$ & $\mathrm{t}-3, \ldots$ & $\mathrm{t}-3, \ldots$ & $\mathrm{t}-3, \ldots$ & $\mathrm{t}-3, \ldots$ & $\mathrm{t}-3, \ldots$ \\
\hline & $\Delta \mathrm{t}-2 \ldots$ & $\Delta \mathrm{t}-2 \ldots$ & $\Delta \mathrm{t}-2 \ldots$ & $\Delta \mathrm{t}-2 \ldots$ & $\Delta \mathrm{t}-2 \ldots$ & $\Delta \mathrm{t}-2 \ldots$ & $\Delta \mathrm{t}-2 \ldots$ & $\Delta \mathrm{t}-2 \ldots$ \\
\hline$\chi^{2}$ (p-value) & 0.186 & 0.091 & 0.033 & 0.039 & 0.473 & 0.164 & 0.263 & 0.473 \\
\hline number of observations & 12,618 & 12,623 & 12,623 & 12,624 & 12,618 & 12,623 & 12,623 & 12,618 \\
\hline
\end{tabular}

Notes: In column 1-4, type 1 is a dummy variable equal to 1 if firm $i$ belong to the group of small young firms, and 0 otherwise. In column $5-8$, type 1 is a dummy variable equal to 1 if firm $i$ exports in year $t$, and 0 otherwise. $\chi^{2}$ tests the differentiated TFP effects under $\mathrm{H}_{0}: \operatorname{logtfp_{\text {it-}1}} \times$ type $1=\log$ tfp $\mathrm{t}_{\mathrm{it}-1} \times(1$-type1). A significant $\chi^{2}$ indicates different TFP effects for the two corresponding groups of firms. Also see notes to Tables 1 and 2.

Table 6 shows the sample splitting tests of Eq. (2) on firms' new equity. All groups of firms attract positive and highly significant productivity effects on new equity. It is the big and/or old firms and exporters always have stronger effects than their respective counterparts, as shown by the significant $\chi^{2}$ tests for all the regressions. The results are persistent and robust. Again, all the tests indicate appropriate regressions. Therefore, we may be confident to summarise that productivity helps firms to raise new equity finance. Big and/or old firms and exporters are able to better utilise productivity to issue more new equities than small young firms and non-exporters respectively.

Finally, Table 7 shows the test results of productivity on firms' longterm debt ratio. All measures of TFP do not seem to have any effect on firms' long-term debt borrowing for all the groups. However, column 4 shows that big and/or old firms have a significantly higher labour productivity effect on long-term debt than small young firms. Column 8 shows that labour productivity helps both exporter and non-exporters to raise long-term debt, though the effects are similar. Again, all of our control variables are reasonable and regression models are all appropriate.

\section{Exogenous policy shock}

Despite the advantage of system GMM estimator in controlling endogeneity problems in our models, we make use of an exogenous industrial policy shock on productivity of firms in some sectors and use a difference-in-difference (DID hereafter) approach to shed some further lights on the causality between productivity and external finance.

The Chinese policy makers believe that some industrial sectors have produced far more than the demand of the market, and have been trying to intervene in the production market. The Chinese government issued the 'Notice of the State Council on Further Strengthening the
Elimination of Backward Production Capacities' (No. 7 [2010] of the State Council) (the Notice hereafter) in June 2010. ${ }^{16}$ This Notice aims to reduce production in sectors including electricity, coke, iron and steel, nonferrous metal, construction materials (particularly cement), some light industries (mainly paper making and leather), and textile. It details various means by the government in an attempt to reduce output in those sectors, such as direct closure and demolishing of production facilities and equipment, increasing the entry requirement, environmental standards, product standards, and monitoring, and etc. For example, the Notice requires firms must retire some production lines with certain old technologies or of very small production capacity. Such measures by the government would damage the productivity in those industries and are completely out of the control of the firms, and we thus may regard it as an exogenous shock to the firms and expect a drop in productivity for firms in those affected industries.

Following Ding et al. (2018) we use a DID approach to explore the effects of such exogenous shock on firms' external finance by estimating the following equation.

extfinance $_{i t}=\alpha+\beta$ Treat $_{i}+\gamma$ Postpolicy $_{t}+\theta$ Treat $_{i} \times$ Postpolicy $_{t}+v_{p}+v_{o}+e_{i t}$

where extfinance $_{i t}$ includes total leverage, new equity and long-term debt variables respectively in separate regressions. Treat $t_{i}$ is a dummy variable equal to 1 if firm $i$ is from the treatment group, i.e. in one of the industries that are affected by the policy, ${ }^{17}$ and 0 otherwise. Postpolicy $y_{t}$

\footnotetext{
${ }^{16}$ The full text of the Notice in Chinese is available in the Chinese central government website http://www.gov.cn/zwgk/2010-04/06/content_1573880. htm

${ }^{17}$ In our sample the treatment group includes firms in the following industries: cement and asbestine cement products; coking; metal products; paper
} 
Table 6

The effect of productivity on new equity.

\begin{tabular}{|c|c|c|c|c|c|c|c|c|}
\hline \multirow[t]{3}{*}{ Dependent variable: new equity ${ }_{\text {it }}$} & \multicolumn{4}{|c|}{ Small \& young/others } & \multicolumn{4}{|c|}{ Exporters/non-exporters } \\
\hline & LP & Wooldridge & $\mathrm{ACF}$ & Labour productivity & LP & Wooldridge & $\mathrm{ACF}$ & Labour productivity \\
\hline & (1) & (2) & (3) & (4) & (5) & (6) & (7) & (8) \\
\hline new equity ${ }_{i, t-1}$ & $\begin{array}{l}-0.081^{* *} \\
(0.040)\end{array}$ & $\begin{array}{l}-0.131^{* * *} \\
(0.040)\end{array}$ & $\begin{array}{l}-0.119^{* * *} \\
(0.038)\end{array}$ & $\begin{array}{l}-0.065 \\
(0.040)\end{array}$ & $\begin{array}{l}-0.040 \\
(0.062)\end{array}$ & $\begin{array}{l}-0.093^{* * *} \\
(0.044)\end{array}$ & $\begin{array}{l}-0.092^{* *} \\
(0.045)\end{array}$ & $\begin{array}{l}-0.022 \\
(0.052)\end{array}$ \\
\hline $\log S_{\text {it-1 }}$ & $\begin{array}{l}-0.027^{* * *} \\
(0.007)\end{array}$ & $\begin{array}{l}-0.095^{\text {**** }} \\
(0.023)\end{array}$ & $\begin{array}{l}-0.071^{* * *} \\
(0.010)\end{array}$ & $\begin{array}{l}-0.043^{* * *} \\
(0.008)\end{array}$ & $\begin{array}{l}-0.016^{*} \\
(0.009)\end{array}$ & $\begin{array}{l}-0.109^{* * *} \\
(0.027)\end{array}$ & $\begin{array}{l}-0.074^{* * *} \\
(0.012)\end{array}$ & $\begin{array}{l}-0.038^{* * *} \\
(0.010)\end{array}$ \\
\hline asset growth ${ }_{\mathrm{it}-1}$ & $\begin{array}{l}-0.004 \\
(0.024)\end{array}$ & $\begin{array}{l}-0.026 \\
(0.024)\end{array}$ & $\begin{array}{l}-0.013 \\
(0.024)\end{array}$ & $\begin{array}{l}-0.045^{*} \\
(0.023)\end{array}$ & $\begin{array}{l}-0.132^{* * *} \\
(0.033)\end{array}$ & $\begin{array}{l}-0.080^{* * *} \\
(0.030)\end{array}$ & $\begin{array}{l}-0.069^{* *} \\
(0.030)\end{array}$ & $\begin{array}{l}-0.116^{* * *} \\
(0.027)\end{array}$ \\
\hline tangibility $\mathrm{it}-1_{1}$ & $\begin{array}{l}0.178^{*} \\
(0.100)\end{array}$ & $\begin{array}{l}0.144 \\
(0.119)\end{array}$ & $\begin{array}{l}0.318^{* * *} \\
(0.121)\end{array}$ & $\begin{array}{l}0.028 \\
(0.112)\end{array}$ & $\begin{array}{l}-0.026 \\
(0.143)\end{array}$ & $\begin{array}{l}0.236^{*} \\
(0.142)\end{array}$ & $\begin{array}{l}0.374^{* *} \\
(0.157)\end{array}$ & $\begin{array}{l}-0.036 \\
(0.149)\end{array}$ \\
\hline roa $_{\text {it-1 }}$ & $\begin{array}{l}0.052 \\
(0.179)\end{array}$ & $\begin{array}{l}0.419^{* *} \\
(0.177)\end{array}$ & $\begin{array}{l}0.383^{* *} \\
(0.179)\end{array}$ & $\begin{array}{l}0.130 \\
(0.166)\end{array}$ & $\begin{array}{l}0.069 \\
(0.267)\end{array}$ & $\begin{array}{l}0.349 \\
(0.220)\end{array}$ & $\begin{array}{l}0.266 \\
(0.227)\end{array}$ & $\begin{array}{l}0.168 \\
(0.242)\end{array}$ \\
\hline dep $_{\text {it-1 }}$ & $\begin{array}{l}0.854^{*} \\
(0.892)\end{array}$ & $\begin{array}{l}1.214 \\
(0.888)\end{array}$ & $\begin{array}{l}1.093 \\
(0.891)\end{array}$ & $\begin{array}{l}1.898^{* *} \\
(0.934)\end{array}$ & $\begin{array}{l}1.190 \\
(1.384)\end{array}$ & $\begin{array}{l}-0.002 \\
(1.108)\end{array}$ & $\begin{array}{l}0.226 \\
(1.139)\end{array}$ & $\begin{array}{l}1.689 \\
(1.341)\end{array}$ \\
\hline $\operatorname{logtfp}_{\text {it-1 }} \times$ type1 & $\begin{array}{l}0.071 \\
(0.056)\end{array}$ & $\begin{array}{l}1.711^{* *} \\
(0.660)\end{array}$ & $\begin{array}{l}0.884^{* * *} \\
(0.213)\end{array}$ & & $\begin{array}{l}0.208^{* *} \\
(0.084)\end{array}$ & $\begin{array}{l}2.260^{* * * *} \\
(0.763)\end{array}$ & $\begin{array}{l}1.077^{* * *} \\
(0.245)\end{array}$ & \\
\hline $\operatorname{logtfp}_{\mathrm{it}-1} \times(1$-type 1$)$ & $\begin{array}{l}0.138^{* *} \\
(0.055)\end{array}$ & $\begin{array}{l}1.729^{* * * *} \\
(0.659)\end{array}$ & $\begin{array}{l}0.911^{\text {**** }} \\
(0.211)\end{array}$ & & $\begin{array}{l}0.144^{*} \\
(0.080)\end{array}$ & $\begin{array}{l}2.246^{* * * *} \\
(0.761)\end{array}$ & $\begin{array}{l}1.054^{* * * *} \\
(0.242)\end{array}$ & \\
\hline labour intensity $y_{i t-1}$ & & & & $\begin{array}{c}-0.009 \\
(0.198)\end{array}$ & & & & $\begin{array}{l}0.439 \\
(0.247)\end{array}$ \\
\hline${\log l p_{i t-1}} \times$ type 1 & & & & $\begin{array}{l}0.041^{* * *} \\
(0.013)\end{array}$ & & & & $\begin{array}{l}0.082^{* * *} \\
(0.017)\end{array}$ \\
\hline $\operatorname{loglp}_{\text {it-1 }} \times(1$-type1) & & & & $\begin{array}{l}0.048^{* * * *} \\
(0.014)\end{array}$ & & & & $\begin{array}{l}0.075^{\text {**** }} \\
(0.017)\end{array}$ \\
\hline m2 (p-value) & 0.746 & & & 0.713 & 0.846 & & & 0.499 \\
\hline m3 (p-value) & & 0.723 & 0.860 & & & 0.777 & 0.998 & \\
\hline $\mathrm{J}$ (Hansen) & 0.159 & 0.118 & 0.172 & 0.235 & 0.185 & 0.079 & 0.102 & 0.125 \\
\hline IVs(lags) & $\mathrm{t}-2, \ldots$ & $\mathrm{t}-3, \ldots$ & $\mathrm{t}-3, \ldots$ & $\mathrm{t}-2, \ldots$ & $\mathrm{t}-2, \ldots$ & $\mathrm{t}-3, \ldots$ & $\mathrm{t}-3, \ldots$ & $\mathrm{t}-2, \ldots$ \\
\hline & $\Delta \mathrm{t}-1 \ldots$ & $\Delta \mathrm{t}-2 \ldots$ & $\Delta \mathrm{t}-2 \ldots$ & $\Delta \mathrm{t}-1 \ldots$ & $\Delta \mathrm{t}-1 \ldots$ & $\Delta \mathrm{t}-2 \ldots$ & $\Delta \mathrm{t}-2 \ldots$ & $\Delta \mathrm{t}-1 \ldots$ \\
\hline$\chi^{2}$ (p-value) & 0.000 & 0.004 & 0.002 & 0.000 & 0.001 & 0.087 & 0.036 & 0.008 \\
\hline number of observations & 12,611 & 12,616 & 12,616 & 12,617 & 12,611 & 12,616 & 12,616 & 12,617 \\
\hline
\end{tabular}

Notes: See notes to Tables 1, 2 and 5.

Table 7

The effect of productivity on long-term debt.

\begin{tabular}{|c|c|c|c|c|c|c|c|c|}
\hline \multirow[t]{3}{*}{ Dependent variable: $\operatorname{ltd}_{\mathrm{it}}$} & \multicolumn{4}{|c|}{ Small \& young/others } & \multicolumn{4}{|c|}{ Exporters/non-exporters } \\
\hline & LP & Wooldridge & $\mathrm{ACF}$ & Labour productivity & LP & Wooldridge & ACF & Labour productivity \\
\hline & (1) & (2) & (3) & (4) & (5) & (6) & (7) & (8) \\
\hline $\operatorname{ltd}_{\mathrm{i}, \mathrm{t}-1}$ & $\begin{array}{l}0.675^{* * * *} \\
(0.029)\end{array}$ & $\begin{array}{l}0.683^{* * * *} \\
(0.027)\end{array}$ & $\begin{array}{l}0.682^{* * *} \\
(0.028)\end{array}$ & $\begin{array}{l}0.665^{* * * *} \\
(0.029)\end{array}$ & $\begin{array}{l}0.790^{\text {**** }} \\
(0.044)\end{array}$ & $\begin{array}{l}0.687^{* * * *} \\
(0.029)\end{array}$ & $\begin{array}{l}0.684^{* * *} \\
(0.030)\end{array}$ & $\begin{array}{l}0.673^{* * *} \\
(0.033)\end{array}$ \\
\hline $\log S_{\text {it-1 }}$ & $\begin{array}{l}-0.002 \\
(0.002)\end{array}$ & $\begin{array}{l}-0.002 \\
(0.005)\end{array}$ & $\begin{array}{l}-0.003 \\
(0.002)\end{array}$ & $\begin{array}{l}-0.002 \\
(0.002)\end{array}$ & $\begin{array}{l}0.002 \\
(0.003)\end{array}$ & $\begin{array}{l}-0.002 \\
(0.006)\end{array}$ & $\begin{array}{l}-0.001 \\
(0.003)\end{array}$ & $\begin{array}{l}0.002 \\
(0.003)\end{array}$ \\
\hline asset growth $\mathrm{it}_{\mathrm{it}}$ & $\begin{array}{l}-0.014^{*} \\
(0.008)\end{array}$ & $\begin{array}{l}-0.013^{*} \\
(0.007)\end{array}$ & $\begin{array}{l}-0.012^{*} \\
(0.008)\end{array}$ & $\begin{array}{l}-0.010 \\
(0.008)\end{array}$ & $\begin{array}{l}-0.018 \\
(0.014)\end{array}$ & $\begin{array}{l}-0.015^{*} \\
(0.008)\end{array}$ & $\begin{array}{l}-0.013 \\
(0.008)\end{array}$ & $\begin{array}{l}-0.017^{*} \\
(0.010)\end{array}$ \\
\hline tangibility $_{\text {it }-1}$ & $\begin{array}{l}0.076^{* *} \\
(0.029)\end{array}$ & $\begin{array}{l}0.062^{* *} \\
(0.031)\end{array}$ & $\begin{array}{l}0.076^{* *} \\
(0.033)\end{array}$ & $\begin{array}{l}0.057^{*} \\
(0.031)\end{array}$ & $\begin{array}{l}-0.014 \\
(0.059)\end{array}$ & $\begin{array}{l}0.049 \\
(0.037)\end{array}$ & $\begin{array}{l}0.063 \\
(0.041)\end{array}$ & $\begin{array}{l}0.065^{*} \\
(0.034)\end{array}$ \\
\hline $\mathrm{roa}_{\mathrm{it}-1}$ & $\begin{array}{l}0.157^{* * * *} \\
(0.053)\end{array}$ & $\begin{array}{l}0.171^{\text {**** }} \\
(0.048)\end{array}$ & $\begin{array}{l}0.166^{* * * *} \\
(0.048)\end{array}$ & $\begin{array}{l}0.165^{* * * *} \\
(0.054)\end{array}$ & $\begin{array}{l}0.258^{\text {**** }} \\
(0.097)\end{array}$ & $\begin{array}{l}0.155^{* * * * *} \\
(0.056)\end{array}$ & $\begin{array}{l}0.139^{* *} \\
(0.055)\end{array}$ & $\begin{array}{l}0.146 * * \\
(0.066)\end{array}$ \\
\hline $\operatorname{dep}_{\text {it-1 }}$ & $\begin{array}{l}-0.561^{* * *} \\
(0.211)\end{array}$ & $\begin{array}{l}-0.477^{* *} \\
(0.213)\end{array}$ & $\begin{array}{l}-0.529^{* *} \\
(0.203)\end{array}$ & $\begin{array}{l}-0.455^{*} \\
(0.242)\end{array}$ & $\begin{array}{l}0.050 \\
(0.463)\end{array}$ & $\begin{array}{l}-0.427^{*} \\
(0.232)\end{array}$ & $\begin{array}{l}-0.494^{* *} \\
(0.225)\end{array}$ & $\begin{array}{l}-0.577^{* *} \\
(0.268)\end{array}$ \\
\hline $\operatorname{logtfp_{it-1}} \times$ type 1 & $\begin{array}{l}0.021 \\
(0.018)\end{array}$ & $\begin{array}{l}-0.003 \\
(0.163)\end{array}$ & $\begin{array}{l}0.032 \\
(0.056)\end{array}$ & & $\begin{array}{l}-0.008 \\
(0.029)\end{array}$ & $\begin{array}{l}0.066 \\
(0.181)\end{array}$ & $\begin{array}{l}0.040 \\
(0.064)\end{array}$ & \\
\hline $\operatorname{logtfp}_{\mathrm{it}-1} \times(1$-type1) & $\begin{array}{l}0.027 \\
(0.018)\end{array}$ & $\begin{array}{l}-0.001 \\
(0.163)\end{array}$ & $\begin{array}{l}0.036 \\
(0.055)\end{array}$ & & $\begin{array}{l}0.001 \\
(0.026)\end{array}$ & $\begin{array}{l}0.068 \\
(0.181)\end{array}$ & $\begin{array}{l}0.042 \\
(0.064)\end{array}$ & \\
\hline labour intensity $y_{\mathrm{it}-1}$ & & & & $\begin{array}{l}0.111^{*} \\
(0.063)\end{array}$ & & & & $\begin{array}{l}0.168^{* *} \\
(0.069)\end{array}$ \\
\hline $\log l p_{i t-1} \times$ type1 & & & & $\begin{array}{l}0.008^{*} \\
(0.004)\end{array}$ & & & & $\begin{array}{l}1.075 \mathrm{e}-1^{* *} \\
(4.91 \mathrm{e}-2)\end{array}$ \\
\hline $\operatorname{loglp}_{\text {it-1 }} \times(1$-type1) & & & & $\begin{array}{l}0.009^{* *} \\
(0.004)\end{array}$ & & & & $\begin{array}{l}1.155 \mathrm{e}-1^{* *} \\
(4.83 \mathrm{e}-2)\end{array}$ \\
\hline $\mathrm{m} 3$ (p-value) & 0.275 & 0.278 & 0.286 & 0.252 & 0.173 & 0.240 & 0.253 & 0.221 \\
\hline $\mathrm{J}$ (Hansen) & 0.356 & 0.301 & 0.163 & 0.366 & 0.873 & 0.445 & 0.310 & 0.412 \\
\hline IVs(lags) & $\mathrm{t}-3, \ldots$ & $\mathrm{t}-3, \ldots$ & $t-3, \ldots$ & $\mathrm{t}-3, \ldots$ & $\mathrm{t}-3, \ldots$ & $\mathrm{t}-3, \ldots$ & $\mathrm{t}-3, \ldots$ & $\mathrm{t}-3, \ldots$ \\
\hline & $\Delta \mathrm{t}-2 \ldots$ & $\Delta \mathrm{t}-2 \ldots$ & $\Delta \mathrm{t}-2 \ldots$ & $\Delta \mathrm{t}-2 \ldots$ & $\Delta \mathrm{t}-2 \ldots$ & $\Delta \mathrm{t}-2 \ldots$ & $\Delta \mathrm{t}-2 \ldots$ & $\Delta \mathrm{t}-2 \ldots$ \\
\hline$\chi^{2}(\mathrm{p}$-value $)$ & 0.154 & 0.145 & 0.085 & 0.029 & 0.327 & 0.537 & 0.451 & 0.315 \\
\hline number of observations & 12,402 & 12,407 & 12,407 & 12,408 & 12,402 & 12,407 & 12,407 & 12,408 \\
\hline
\end{tabular}

Notes: See notes to Tables 1, 2 and 5. 
is a dummy variable equal to 1 if the observation is in the post-treatment period, i.e. in or after 2012. The Notice specifies that those productivity-damaging measures in those industries have to be implemented by the end of 2011. ${ }^{18}$ Therefore, we regard 2010 and 2011 as our treatment period, and 2012 onwards as post-treatment period. We also include province and ownership dummies, $v_{p}$ and $v_{o} . e_{i t}$ is an idiosyncratic error term. The strict exogenous assumption of DID implies that $\theta$ is the DID treatment effect of the policy shock we examine, i.e. the effect of the policy on the treatment group. Specifically,

$$
\begin{aligned}
\theta & =\left\{E \left[\text { extfinance }_{i t} \mid \text { Treat }_{i}\right.\right. \\
= & \left.1, \text { Postpolicy }_{t}=1\right]-E\left[\text { extfinance }_{i t} \mid \text { Treat }_{i}\right. \\
& \left.\left.=1, \text { Postpolicy }_{t}=0\right]\right\} \\
-\left\{E \left[\text { extfinance }_{i t} \mid \text { Treat }_{i}\right.\right. & \left.=0, \text { Postpolicy }_{t}=1\right]-E\left[\text { extfinance }_{i t} \mid \text { Treat }_{i}\right. \\
& \left.\left.=0, \text { Postpolicy }_{t}=0\right]\right\}
\end{aligned}
$$

$\beta$ is the difference between the treatment and non-treatment groups during the pre-policy period, i.e. 2009 and before, and $\gamma$ is the change after the implementation of the policy for the non-treatment group. More specifically,

$$
\begin{aligned}
\beta & =\mathrm{E}\left[\text { extfinance }_{i t} \mid \text { Treat }_{i}=1, \text { Postpolicy }_{t}=0\right]-\mathrm{E}\left[\text { extfinance }_{i t} \mid \text { Treat }_{i}\right. \\
& \left.=0, \text { Postpolicy }_{t}=0\right]
\end{aligned}
$$

$\gamma=\mathrm{E}\left[\right.$ extfinance $_{i t} \mid$ Treat $_{i}=0$, Postpolicy $\left._{t}=1\right]-\mathrm{E}\left[\right.$ extfinance $_{i t} \mid$ Treat $_{i}$

$$
\left.=0, \text { Postpolicy }_{t}=0\right]
$$

The results of the DID regressions in Eq. (3) are reported in Table 8. Before the policy shock, firms in the treatment sectors have $4.1 \%$ and $2.7 \%(\beta)$ higher leverage and long-term debt respectively, but $2.4 \%$ less new equity comparing to firms in other sectors. The policy shock has a particularly significant negative effect on firms' long-term debt, which is reduced by $2.6 \%(\gamma+\theta)$ in those treatment industries compared to the pre-policy period. The reduction is also $1.7 \%(\theta)$ more than firms in other non-treatment industries. However, the treatment effect $(\theta)$ for the total leverage and new equity is not particularly obvious.

We then split our sample into small young firms versus other firms and exporters versus non-exporters, and run the regressions of Eq. (3) for each type of external finance. The results are presented in Table 9. The policy shock does not have a significant treatment effect $(\theta)$ on leverage for all the sub-groups as shown in column 1 and 2 . In the new equity regressions in panel A of column 3 and 4, large and/or old firms have a strong treatment effect, whereas small young firms do not. In panel B, neither exporters nor non-exporters have any significant treatment effects. In column 5 and 6 , large and/or old firms have a significant negative treatment effect on long-term debt, whereas small young firms do not. Exporters have a significant negative treatment effect on long-term debt, whereas non-exporters do not. These results are consistent with our GMM regression results, i.e. the external finance of large and/or old firms and exporters is more responsive to their productivity.

Overall, our DID results confirm the causality from productivity to external finance, and provide additional support for the validity of our main GMM regression results. In particular, we find this productivitydamaging policy significantly reduces external finance for firms in the affected industries relative to other firms. Such effects exist for the

\section{(footnote continued)}

making and paper products; production of leather, fur down and related products; smelting and pressing of ferrous metals; smelting and pressing of nonferrous metal; and textile.

\begin{tabular}{|c|c|c|c|}
\hline \multirow[t]{2}{*}{ Dependent variable } & leverage $_{i t}$ & new equity ${ }_{\text {it }}$ & $\operatorname{ltd}_{\mathrm{it}}$ \\
\hline & (1) & (2) & (3) \\
\hline Treat $_{i}(\beta)$ & $\begin{array}{l}0.041^{\text {**** }} \\
(0.011)\end{array}$ & $\begin{array}{l}-0.024^{* *} \\
(0.011)\end{array}$ & $\begin{array}{l}0.027^{* * *} \\
(0.003)\end{array}$ \\
\hline Postpolicy $_{t}(\gamma)$ & $\begin{array}{l}-0.071^{* * * *} \\
(0.006)\end{array}$ & $\begin{array}{l}-0.046^{* * *} \\
(0.008)\end{array}$ & $\begin{array}{l}-0.009^{* * * *} \\
(0.002)\end{array}$ \\
\hline Treat $_{\mathrm{i}} \times$ Postpolicy $_{\mathrm{t}}(\theta)$ & $\begin{array}{l}0.009 \\
(0.015)\end{array}$ & $\begin{array}{l}-0.019 \\
(0.014)\end{array}$ & $\begin{array}{l}-0.017^{* * *} \\
(0.004)\end{array}$ \\
\hline$R^{2}$ & 0.050 & 0.036 & 0.062 \\
\hline Number of observations & 14,949 & 14,944 & 14,739 \\
\hline
\end{tabular}

${ }^{18}$ According to the Notice the only exception is the cement sector, which was allowed to comply with the new regulation by the end of 2012. However, the proportion of cement firms in our sample is small and it is more reasonable to use 2010 and 2011 as the treatment period.
Table 8

The effects of exogenous policy shock on external finance.

Notes: The table reports the OLS results of the difference-in-difference estimation in Eq. (3). The standard errors of estimated coefficients are reported in the parentheses. Treat $t$ is a dummy variable equal to 1 if firm $i$ is in one of the following manufacturing industries: cement and asbestine cement products; coking; metal products; paper making and paper products; production of leather, fur, down and related products; smelting and pressing of ferrous metals; smelting and pressing of non-ferrous metals; and textile, and 0 otherwise. Postpolicy $_{t}$ is a dummy variable equal to 1 if the observation is in year 2012 to 2016, and 0 otherwise. Ownership dummies and province dummies are included in all the regressions.

better quality large and/old firms and exporters, but not for their respective counterparts.

\section{Conclusion}

Using a panel of 1591 Chinese listed manufacturing firms between year 2003-2016 we find that productivity measured by three TFP estimation methods and labour productivity is statistically and economically important and positive in determining firms' external finance, i.e. total leverage, new issue of equity and long-term debt. We find strong and robust results that productivity is helpful for firms to raise new equity finance, but some weaker results for total leverage and long-term debt. Such results hold for both the whole sample and private firms separately. Our findings are sensible that external lenders would be most interested in firms' ability in repaying debt, and less interested in how efficient firms are. On the other hand, equity investors would be most interested in firms' long-term operation as productive firms are more likely to give them better return in the long run. Therefore, productivity that indicates firms' overall quality would matter more for equity investors and perhaps less for debt lenders as our results show.

We also find that large and/or old firms and exporting firms are able to make better use of their productivity to gain external finance than their respective counterparts, i.e. small young firms and non-exporting firms. Again, the results are mainly valid for new equity finance, but not quite for total leverage and long-term debt. Large and/or old firms are less likely to suffer from information asymmetry problems, and are often perceived to have better quality than small young firms by outsiders. Exporters are also more likely to be the better firms than nonexporters given the fact that they can afford the substantial sunk cost of exporting. Thus, our results also suggest that better firms are able to utilise productivity more to gain external finance.

We further confirm the causality of our results by using DID regressions following an exogenous industrial policy shock during year 2010-2011. We find that this productivity-damaging policy indeed reduces external finance for firms in the affected industries.

Our research suggests a highly important relationship in the financial market, i.e. despite the presence of information asymmetry, productive good firms do get more external finance. This is an encouraging discovery of a possible virtuous circle between productivity and finance. In addition our sample splitting test results give a further important implication that productivity not only enables all firms to raise external finance, the mechanism also forces financial resources to 
Table 9

The effects of exogenous policy shock on external finance.

\begin{tabular}{|c|c|c|c|c|c|c|}
\hline \multicolumn{7}{|l|}{ Panel A } \\
\hline \multirow[t]{3}{*}{ Dependent variable } & \multicolumn{2}{|l|}{ leverage $_{i t}$} & \multicolumn{2}{|l|}{ new equity ${ }_{i t}$} & \multicolumn{2}{|l|}{$\operatorname{ltd}_{\text {it }}$} \\
\hline & (1) & (2) & (3) & (4) & (5) & (6) \\
\hline & Small \& young & Others & Small \& young & Others & Small \& young & Others \\
\hline Treat $_{i}(\beta)$ & $\begin{array}{l}0.075^{\text {**** }} \\
(0.022)\end{array}$ & $\begin{array}{l}0.020^{*} \\
(0.012)\end{array}$ & $\begin{array}{l}-0.059^{*} \\
(0.030)\end{array}$ & $\begin{array}{l}-0.002 \\
(0.010)\end{array}$ & $\begin{array}{l}0.013^{* *} \\
(0.006)\end{array}$ & $\begin{array}{l}0.029^{* * * *} \\
(0.004)\end{array}$ \\
\hline Postpolicy $_{t}(\gamma)$ & $\begin{array}{l}-0.149^{* * *} \\
(0.011)\end{array}$ & $\begin{array}{l}-0.087^{* * * *} \\
(0.007)\end{array}$ & $\begin{array}{l}-0.197^{* * *} \\
(0.027)\end{array}$ & $\begin{array}{l}0.001 \\
(0.007)\end{array}$ & $\begin{array}{l}-0.020^{* * *} \\
(0.003)\end{array}$ & $\begin{array}{l}-0.011^{* * * *} \\
(0.002)\end{array}$ \\
\hline Treat $_{i} \times$ Postpolicy $_{t}(\theta)$ & $\begin{array}{l}-0.018 \\
(0.033)\end{array}$ & $\begin{array}{l}0.017 \\
(0.016)\end{array}$ & $\begin{array}{l}-0.039 \\
(0.049)\end{array}$ & $\begin{array}{l}-0.037^{* * * *} \\
(0.014)\end{array}$ & $\begin{array}{l}-0.003 \\
(0.008)\end{array}$ & $\begin{array}{l}-0.021^{* * * *} \\
(0.005)\end{array}$ \\
\hline $\begin{array}{l}R^{2} \\
\text { number of observations }\end{array}$ & $\begin{array}{l}0.127 \\
2918\end{array}$ & $\begin{array}{l}0.047 \\
12,031\end{array}$ & $\begin{array}{l}0.085 \\
2918\end{array}$ & $\begin{array}{l}0.022 \\
12,026\end{array}$ & $\begin{array}{l}0.121 \\
2897\end{array}$ & $\begin{array}{l}0.063 \\
11,842\end{array}$ \\
\hline \multicolumn{7}{|l|}{ Panel B } \\
\hline \multirow[t]{3}{*}{ Dependent variable } & \multicolumn{2}{|l|}{ leverage $_{\text {it }}$} & \multicolumn{2}{|l|}{ New equity ${ }_{i t}$} & \multicolumn{2}{|l|}{$\operatorname{ltd}_{\text {it }}$} \\
\hline & (1) & (2) & (3) & (4) & (5) & (6) \\
\hline & Exporter & Non-exporter & Exporter & Non-exporter & Exporter & Non-exporter \\
\hline Treat $_{i}(\beta)$ & $\begin{array}{l}0.005 \\
(0.013)\end{array}$ & $\begin{array}{l}0.077^{* * * *} \\
(0.018)\end{array}$ & $\begin{array}{l}-0.039^{* *} \\
(0.016)\end{array}$ & $\begin{array}{l}-0.017 \\
(0.015)\end{array}$ & $\begin{array}{l}0.017^{* * * *} \\
(0.004)\end{array}$ & $\begin{array}{l}0.035^{* * *} \\
(0.005)\end{array}$ \\
\hline Postpolicy $_{t}(\gamma)$ & $\begin{array}{l}-0.075^{* * * *} \\
(0.008)\end{array}$ & $\begin{array}{l}-0.068^{* * *} \\
(0.010)\end{array}$ & $\begin{array}{l}-0.077^{* * *} \\
(0.011)\end{array}$ & $\begin{array}{l}0.016 \\
(0.011)\end{array}$ & $\begin{array}{l}-0.014^{* * * *} \\
(0.002)\end{array}$ & $\begin{array}{l}-0.004 \\
(0.003)\end{array}$ \\
\hline Treat $_{\mathrm{i}} \times$ Postpolicy $_{\mathrm{t}}(\theta)$ & $\begin{array}{l}0.017 \\
(0.017)\end{array}$ & $\begin{array}{l}0.034 \\
(0.028)\end{array}$ & $\begin{array}{l}-0.010 \\
(0.099)\end{array}$ & $\begin{array}{l}-0.014 \\
(0.025)\end{array}$ & $\begin{array}{l}-0.013^{* * *} \\
(0.005)\end{array}$ & $\begin{array}{l}-0.011 \\
(0.008)\end{array}$ \\
\hline$R^{2}$ & 0.072 & 0.044 & 0.040 & 0.039 & 0.078 & 0.064 \\
\hline number of observations & 8714 & 6235 & 8710 & 6234 & 8568 & 6174 \\
\hline
\end{tabular}

Notes: see notes to Table 8 .

shift towards the better quality firms and away from unproductive firms.

Overall, our findings suggest that productivity is a good indicator of firms' quality in the financial market, which could possibly reduce the information asymmetry problem to some extent. If government policies and regulations may target at channelling financial resources to productive firms, it will contribute to improve aggregate productivity and is certainly beneficial to an economy's sustainable growth in the long term. Such mechanism would also contribute to a more sustainable financial system itself, given that lenders and investors may find their funds exposed to less risk in the hands of truly efficient firms. A wellfunctioning financial market, even if it is frictional and costly for firms to access, always generates a welfare gain. This is however beyond the scope of this paper, and can be proved in a future study.

\section{Appendix A. Appendix}

\section{A.1. Panel data structure}

Table A1

Panel year structure.

\begin{tabular}{llrr}
\hline Year & Number of observations & Percent & Cumulative \\
\hline 2003 & 587 & 4.65 & 4.65 \\
2004 & 659 & 5.22 & 9.87 \\
2005 & 688 & 5.45 & 15.33 \\
2006 & 749 & 5.94 & 21.26 \\
2007 & 750 & 5.94 & 27.21 \\
2008 & 802 & 6.36 & 33.56 \\
2009 & 759 & 6.02 & 39.58 \\
2010 & 782 & 6.20 & 45.78 \\
2011 & 879 & 6.97 & 52.74 \\
2012 & 1187 & 9.41 & 62.15 \\
2013 & 1349 & 10.69 & 72.84 \\
2014 & 1432 & 11.35 & 84.19 \\
2015 & 1468 & 11.63 & 95.82 \\
2016 & 527 & 4.18 & 100.00 \\
\hline
\end{tabular}


Table A2

Panel years per firm structure.

\begin{tabular}{|c|c|c|c|}
\hline Number of years per firm & Number of observations & Percent & Cumulative \\
\hline 4 & 44 & 0.35 & 0.35 \\
\hline 5 & 102 & 0.81 & 1.16 \\
\hline 6 & 374 & 2.96 & 4.12 \\
\hline 7 & 791 & 6.27 & 10.39 \\
\hline 8 & 794 & 6.29 & 16.68 \\
\hline 9 & 345 & 2.73 & 19.42 \\
\hline 10 & 308 & 2.44 & 21.86 \\
\hline 11 & 501 & 3.97 & 25.83 \\
\hline 12 & 308 & 2.44 & 28.27 \\
\hline 13 & 406 & 3.22 & 31.49 \\
\hline 14 & 503 & 3.99 & 35.47 \\
\hline 15 & 465 & 3.69 & 39.16 \\
\hline 16 & 3398 & 26.93 & 66.09 \\
\hline 17 & 4279 & 33.91 & 100.00 \\
\hline Total & 12,618 & 100.00 & \\
\hline
\end{tabular}

Table A3

Panel ownership structure.

\begin{tabular}{|c|c|c|c|}
\hline Ownership types & Number of observations & Percent & Cumulative \\
\hline Central state & 3001 & 23.78 & 23.78 \\
\hline Lower level state & 2903 & 23.01 & 46.79 \\
\hline Domestic private & 5672 & 44.95 & 91.74 \\
\hline Foreign & 536 & 4.25 & 95.99 \\
\hline Others & 506 & 4.01 & 100.00 \\
\hline Total & 12,618 & 100.00 & \\
\hline
\end{tabular}

\section{A.2. Variable definitions}

TFP_LP: estimated using the Levinsohn and Petrin (2003) method with the revenue function, applied separately to each 2-digit manufacturing industrial group. The levpet Stata command was used in estimation. Also see Chen and Guariglia (2011) for more discussions. We use firms' real total operating revenue as the proxy for revenue, real operating expense for intermediate input, real net fixed assets for capital and total number of employees for labour.

TFP_Wooldridge: estimated using the Wooldridge (2009) GMM method applied separately for each 2-digit manufacturing industrial group. The prodest Stata command was used in estimation. We use real total operating revenue for revenue, total number of employee for labour, real net fixed assets for capital, and following Imrohoroglu and Tüzel (2014) by using (operating cost - total wage) in real term for intermediate input and (total operating revenue - intermediate input) in real term for output (added value).

TFP_acf: estimated using the Ackerberg et al. (2015) method applied separately for each 2-digit manufacturing industrial group. The prodest Stata command was used in estimation. The definition of the variables is the same as the TFP_Wooldridge.

Labour productivity: real sales/number of employee.

Sales: operational revenue.

Leverage: total liabilities/total assets.

New equity: [(change of total shareholders' equity from year t-1 to t) - (change of retained earnings from t-1 to t)]/total assets at t-1. This definition follows Baker et al. (2003).

Long-term debt: firms' outstanding long-term debt with maturity over 12 months/total assets.

Asset growth: change of the logarithm of net fixed assets from t-1 to t.

Tangibility: total tangible assets/total assets.

Roa: net profit/total assets.

Depreciation: depreciation of fixed assets, oil and gas assets and bearer biological assets.

Labour intensity: cash paid to and on behalf of employees, including pay to retired staff/operational revenue.

Liquidity: (current assets - current liabilities)/total assets.

Coverage ratio: net profit/current liabilities.

Deflators: taken from the China Statistical Yearbook (various issues), which are published by the National Bureau of Statistics of China. The provincial capital goods deflator was used to deflate the capital stock, and the provincial producer price indices (PPI) for manufactured goods to deflate other variables, e.g. sales. 


\section{A.3. More robustness check results}

Table A4

The effect of productivity on the changes of total leverage.

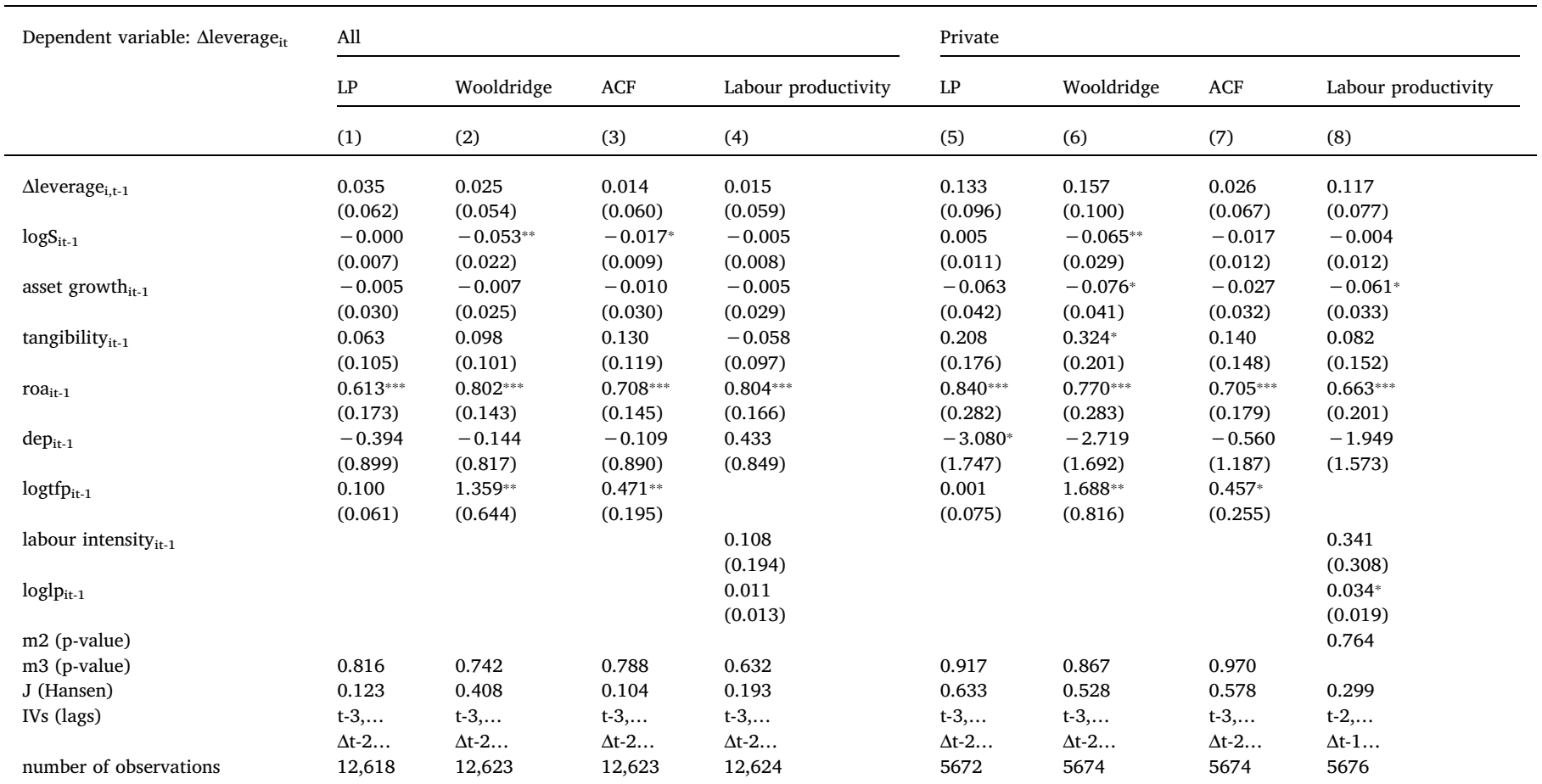

Notes: All specifications were estimated using system GMM estimators. $i$ indexes firms; and $t$, time. All the regressions include year dummies, industry dummies which are at 2 digit level, and province dummies which indicate the location of firms' headquarter. The whole sample regressions also include ownership dummies. The figures reported in parentheses are asymptotic standard errors. $\mathrm{m} 2$ and $\mathrm{m} 3$ are tests for second- and third-order serial correlations in the first-differenced residuals, asymptotically distributed as $\mathrm{N}(0,1)$ under the null of no serial correlation. $\mathrm{J}$ tests show the validity of the instrument sets. * indicates significance at the $10 \%$ level. ** indicates significance at the $5 \%$ level. ${ }^{* * * *}$ indicates significance at the $1 \%$ level. Also see Notes to Table 1 .

Table A5

The effect of productivity on current leverage.

\begin{tabular}{|c|c|c|c|c|c|c|c|c|}
\hline \multirow[t]{3}{*}{ Dependent variable: current leverage $_{i t}$} & \multicolumn{4}{|l|}{ All } & \multicolumn{4}{|l|}{ Private } \\
\hline & LP & Wooldridge & ACF & Labour productivity & LP & Wooldridge & ACF & Labour productivity \\
\hline & $(1)$ & $(2)$ & (3) & (4) & $(5)$ & (6) & (7) & $(8)$ \\
\hline current leverage $\mathrm{e}_{\mathrm{i}, \mathrm{t}-\mathrm{1}}$ & $\begin{array}{l}0.661^{\text {**** }} \\
(0.037)\end{array}$ & $\begin{array}{l}0.621^{* * * *} \\
(0.039)\end{array}$ & $\begin{array}{l}0.610^{* * *} \\
(0.040)\end{array}$ & $\begin{array}{l}0.631^{* * * *} \\
(0.038)\end{array}$ & $\begin{array}{l}0.730^{\text {**** }} \\
(0.062)\end{array}$ & $\begin{array}{l}0.737^{* * * *} \\
(0.061)\end{array}$ & $\begin{array}{l}0.720^{\text {**** }} \\
(0.061)\end{array}$ & $\begin{array}{l}0.711^{\text {**** }} \\
(0.053)\end{array}$ \\
\hline $\log S_{\text {it-1 }}$ & $\begin{array}{l}0.012^{*} \\
(0.006)\end{array}$ & $\begin{array}{l}-0.036 \\
(0.025)\end{array}$ & $\begin{array}{l}-0.008 \\
(0.010)\end{array}$ & $\begin{array}{l}0.020^{* * * *} \\
(0.007)\end{array}$ & $\begin{array}{l}0.005 \\
(0.009)\end{array}$ & $\begin{array}{l}0.026 \\
(0.058)\end{array}$ & $\begin{array}{l}-0.002 \\
(0.016)\end{array}$ & $\begin{array}{l}0.004 \\
(0.012)\end{array}$ \\
\hline asset growth ${ }_{\text {it-1 }}$ & $\begin{array}{l}-0.154^{* * *} \\
(0.023)\end{array}$ & $\begin{array}{l}-0.183^{* * * *} \\
(0.024)\end{array}$ & $\begin{array}{l}-0.180^{\text {**** }} \\
(0.026)\end{array}$ & $\begin{array}{l}-0.157^{\text {**** }} \\
(0.022)\end{array}$ & $\begin{array}{l}-0.174^{* * * *} \\
(0.039)\end{array}$ & $\begin{array}{l}-0.202^{* * *} \\
(0.039)\end{array}$ & $\begin{array}{l}-0.202^{* * *} \\
(0.042)\end{array}$ & $\begin{array}{l}-0.157^{* * * *} \\
(0.037)\end{array}$ \\
\hline tangibility $_{\mathrm{it}-1}$ & $\begin{array}{l}0.320^{* * * *} \\
(0.099)\end{array}$ & $\begin{array}{l}0.422^{* * * *} \\
(0.117)\end{array}$ & $\begin{array}{l}0.424^{* * *} \\
(0.124)\end{array}$ & $\begin{array}{l}0.374^{* * * *} \\
(0.094)\end{array}$ & $\begin{array}{l}0.406^{* *} \\
(0.183)\end{array}$ & $\begin{array}{l}0.475^{* *} \\
(0.196)\end{array}$ & $\begin{array}{l}0.482^{* *} \\
(0.191)\end{array}$ & $\begin{array}{l}0.504^{* * * *} \\
(0.170)\end{array}$ \\
\hline roa $_{\text {it-1 }}$ & $\begin{array}{l}-0.132 \\
(0.172)\end{array}$ & $\begin{array}{l}-0.580^{* * *} \\
(0.161)\end{array}$ & $\begin{array}{l}-0.504^{* * *} \\
(0.161)\end{array}$ & $\begin{array}{l}-0.128 \\
(0.137)\end{array}$ & $\begin{array}{l}-0.324 \\
(0.242)\end{array}$ & $\begin{array}{l}-0.351 \\
(0.229)\end{array}$ & $\begin{array}{l}-0.362 \\
(0.226)\end{array}$ & $\begin{array}{l}-0.142 \\
(0.212)\end{array}$ \\
\hline dep $_{\text {it-1 }}$ & $\begin{array}{l}-3.912^{* * *} \\
(0.811)\end{array}$ & $\begin{array}{l}-3.112^{* * *} \\
(0.864)\end{array}$ & $\begin{array}{l}-3.285^{* * * *} \\
(0.835)\end{array}$ & $\begin{array}{l}-4.059^{* * * *} \\
(0.785)\end{array}$ & $\begin{array}{l}-4.233^{* *} \\
(1.808)\end{array}$ & $\begin{array}{l}-5.455^{* * *} \\
(1.718)\end{array}$ & $\begin{array}{l}-4.948^{* * *} \\
(1.670)\end{array}$ & $\begin{array}{l}-4.754^{* * *} \\
(1.643)\end{array}$ \\
\hline $\operatorname{logtf} \mathrm{p}_{\mathrm{it}-1}$ & $\begin{array}{l}-0.070 \\
(0.063)\end{array}$ & $\begin{array}{l}1.367^{*} \\
(0.701)\end{array}$ & $\begin{array}{l}0.384^{*} \\
(0.231)\end{array}$ & & $\begin{array}{l}-0.003 \\
(0.078)\end{array}$ & $\begin{array}{l}-0.667 \\
(1.545)\end{array}$ & $\begin{array}{l}0.131 \\
(0.326)\end{array}$ & \\
\hline labour intensity $y_{\mathrm{it}-1}$ & & & & $\begin{array}{l}0.245 \\
(0.182)\end{array}$ & & & & $\begin{array}{l}0.110 \\
(0.329)\end{array}$ \\
\hline $\log l p_{i t-1}$ & & & & $\begin{array}{l}-0.015 \\
(0.012)\end{array}$ & & & & $\begin{array}{c}-0.004 \\
(0.024)\end{array}$ \\
\hline m3 (p-value) & 0.933 & & & 0.936 & 0.668 & 0.699 & 0.716 & 0.577 \\
\hline m4 (p-value) & & 0.957 & 0.955 & & & & & \\
\hline $\mathrm{J}$ (Hansen) & 0.146 & 0.260 & 0.117 & 0.209 & 0.544 & 0.392 & 0.352 & 0.149 \\
\hline IVs (lags) & $\mathrm{t}-3, \ldots$ & $\mathrm{t}-4,7 \ldots$ & $\mathrm{t}-4, \ldots$ & $\mathrm{t}-3, \ldots$ & $\mathrm{t}-3, \ldots$ & $\mathrm{t}-3, \ldots$ & $\mathrm{t}-3, \ldots$ & $\mathrm{t}-3, \ldots$ \\
\hline & $\Delta \mathrm{t}-2 \ldots$ & $\Delta \mathrm{t}-3 \ldots$ & $\Delta \mathrm{t}-3 \ldots$ & $\Delta \mathrm{t}-2 \ldots$ & $\Delta \mathrm{t}-2 \ldots$ & $\Delta \mathrm{t}-2 \ldots$ & $\Delta \mathrm{t}-2 \ldots$ & $\Delta \mathrm{t}-2 \ldots$ \\
\hline number of observations & 12,616 & 12,621 & 12,623 & 12,622 & 5671 & 5673 & 5673 & 5675 \\
\hline
\end{tabular}

Notes: see notes to Tables 1 and 2. 
Table A6

The effect of productivity on short-term debt.

\begin{tabular}{|c|c|c|c|c|c|c|c|c|}
\hline \multirow[t]{3}{*}{ Dependent variable: $\operatorname{std}_{i t}$} & \multicolumn{4}{|l|}{ All } & \multicolumn{4}{|l|}{ Private } \\
\hline & LP & Wooldridge & $\mathrm{ACF}$ & Labour productivity & LP & Wooldridge & ACF & Labour productivity \\
\hline & (1) & (2) & (3) & (4) & (5) & (6) & (7) & (8) \\
\hline $\operatorname{std}_{i, t-1}$ & $\begin{array}{l}0.643^{* * * *} \\
(0.055)\end{array}$ & $\begin{array}{l}0.676^{\text {**** }} \\
(0.030)\end{array}$ & $\begin{array}{l}0.704^{* * *} \\
(0.044)\end{array}$ & $\begin{array}{l}0.615^{\text {****}} \\
(0.055)\end{array}$ & $\begin{array}{l}0.579^{* * *} \\
(0.049)\end{array}$ & $\begin{array}{l}0.635^{\text {**** }} \\
(0.062)\end{array}$ & $\begin{array}{l}0.504^{* * * *} \\
(0.049)\end{array}$ & $\begin{array}{l}0.642^{* * * *} \\
(0.059)\end{array}$ \\
\hline $\log S_{i t-1}$ & $\begin{array}{l}0.009^{* *} \\
(0.005)\end{array}$ & $\begin{array}{l}0.007 \\
(0.008)\end{array}$ & $\begin{array}{l}0.003 \\
(0.005)\end{array}$ & $\begin{array}{l}0.007^{* * *} \\
(0.004)\end{array}$ & $\begin{array}{l}0.009^{* *} \\
(0.004)\end{array}$ & $\begin{array}{l}-0.003 \\
(0.011)\end{array}$ & $\begin{array}{l}0.009^{*} \\
(0.005)\end{array}$ & $\begin{array}{l}0.011^{*} \\
(0.006)\end{array}$ \\
\hline asset growth $\mathrm{it-1}_{1}$ & $\begin{array}{l}-0.035^{*} \\
(0.019)\end{array}$ & $\begin{array}{l}-0.029^{* * *} \\
(0.010)\end{array}$ & $\begin{array}{l}-0.045^{* *} \\
(0.018)\end{array}$ & $\begin{array}{l}-0.042^{* *} \\
(0.019)\end{array}$ & $\begin{array}{l}-0.046^{* * * *} \\
(0.015)\end{array}$ & $\begin{array}{l}-0.048^{* * * *} \\
(0.017)\end{array}$ & $\begin{array}{l}-0.043^{* * *} \\
(0.013)\end{array}$ & $\begin{array}{l}-0.039^{* *} \\
(0.019)\end{array}$ \\
\hline tangibility $\mathrm{it}-1_{1}$ & $\begin{array}{l}0.228^{* * *} \\
(0.075)\end{array}$ & $\begin{array}{l}0.191^{* * * *} \\
(0.050)\end{array}$ & $\begin{array}{l}0.238^{* * * *} \\
(0.086)\end{array}$ & $\begin{array}{l}0.262^{* * *} \\
(0.061)\end{array}$ & $\begin{array}{l}0.343^{* * * *} \\
(0.082)\end{array}$ & $\begin{array}{l}0.459^{* * *} \\
(0.111)\end{array}$ & $\begin{array}{l}0.269^{* * * *} \\
(0.103)\end{array}$ & $\begin{array}{l}0.387^{* * * *} \\
(0.101)\end{array}$ \\
\hline roa $_{\text {it-1 }}$ & $\begin{array}{l}-0.248^{* *} \\
(0.108)\end{array}$ & $\begin{array}{l}-0.016 \\
(0.074)\end{array}$ & $\begin{array}{l}0.187^{*} \\
(0.109)\end{array}$ & $\begin{array}{l}-0.234^{* *} \\
(0.102)\end{array}$ & $\begin{array}{l}0.008 \\
(0.096)\end{array}$ & $\begin{array}{l}0.049 \\
(0.131)\end{array}$ & $\begin{array}{l}-0.024 \\
(0.074)\end{array}$ & $\begin{array}{l}0.081 \\
(0.135)\end{array}$ \\
\hline $\operatorname{dep}_{\mathrm{it}-1}$ & $\begin{array}{l}-2.097^{* * *} \\
(0.609)\end{array}$ & $\begin{array}{l}-1.304^{* * * *} \\
(0.389)\end{array}$ & $\begin{array}{l}-1.664^{* *} \\
(0.658)\end{array}$ & $\begin{array}{l}-2.148^{* * * *} \\
(0.563)\end{array}$ & $\begin{array}{l}-2.685^{* * * *} \\
(0.770)\end{array}$ & $\begin{array}{l}-3.346^{* * * *} \\
(0.939)\end{array}$ & $\begin{array}{l}-1.761^{* *} \\
(0.803)\end{array}$ & $\begin{array}{l}-3.168^{* * *} \\
(0.964)\end{array}$ \\
\hline $\operatorname{logtfp} \mathrm{p}_{\mathrm{it}-1}$ & $\begin{array}{l}-0.049 \\
(0.040)\end{array}$ & $\begin{array}{l}-0.066 \\
(0.239)\end{array}$ & $\begin{array}{l}-0.005 \\
(0.106)\end{array}$ & & $\begin{array}{l}-0.016 \\
(0.027)\end{array}$ & $\begin{array}{l}0.269 \\
(0.344)\end{array}$ & $\begin{array}{l}-0.044 \\
(0.121)\end{array}$ & \\
\hline labour intensity $_{\text {it }-1}$ & & & & $\begin{array}{l}-0.103 \\
(0.139)\end{array}$ & & & & $\begin{array}{l}-0.011 \\
(0.172)\end{array}$ \\
\hline $\log l p_{i t-1}$ & & & & $\begin{array}{l}-0.012 \\
(0.009)\end{array}$ & & & & $\begin{array}{l}-0.013 \\
(0.012)\end{array}$ \\
\hline m3 (p-value) & & 0.781 & 0.615 & & 0.638 & 0.61 & 0.768 & 0.606 \\
\hline m4 (p-value) & 0.796 & & & 0.846 & & & & \\
\hline $\mathrm{J}$ (Hansen) & 0.412 & 0.118 & 0.125 & 0.145 & 0.292 & 0.776 & 0.977 & 0.648 \\
\hline IVs (lags) & $t-4, \ldots$ & $\mathrm{t}-3, \ldots$ & $\mathrm{t}-3, \ldots$ & $\mathrm{t}-4, \ldots$ & $\mathrm{t}-3, \ldots$ & $\mathrm{t}-3, \ldots$ & $\mathrm{t}-3, \ldots$ & $\mathrm{t}-3, \ldots$ \\
\hline & $\Delta \mathrm{t}-3 \ldots$ & $\Delta \mathrm{t}-2 \ldots$ & $\Delta \mathrm{t}-2 \ldots$ & $\Delta \mathrm{t}-3 \ldots$ & $\Delta \mathrm{t}-2 \ldots$ & $\Delta \mathrm{t}-2 \ldots$ & $\Delta \mathrm{t}-2 \ldots$ & $\Delta \mathrm{t}-2 \ldots$ \\
\hline number of observations & 12,614 & 12,619 & 12,619 & 12,620 & 5672 & 5674 & 5674 & 5676 \\
\hline
\end{tabular}

Notes: see notes to Tables 1 and 2 .

Table A7

The effect of productivity (moving average) on total leverage.

\begin{tabular}{|c|c|c|c|c|c|c|c|c|}
\hline \multirow[t]{3}{*}{ Dependent variable: total leverage ${ }_{i t}$} & \multicolumn{4}{|l|}{ All } & \multicolumn{4}{|l|}{ Private } \\
\hline & LP & Wooldridge & ACF & Labour productivity & LP & Wooldridge & ACF & Labour productivity \\
\hline & (1) & (2) & (3) & (4) & (5) & (6) & (7) & (8) \\
\hline total leverage $\mathrm{e}_{\mathrm{i}, \mathrm{t}-1}$ & $\begin{array}{l}0.663^{* * *} \\
(0.037)\end{array}$ & $\begin{array}{l}0.676^{* * *} \\
(0.034)\end{array}$ & $\begin{array}{l}0.646^{* * *} \\
(0.034)\end{array}$ & $\begin{array}{l}0.639^{* * *} \\
(0.037)\end{array}$ & $\begin{array}{l}0.695^{* * * *} \\
(0.043)\end{array}$ & $\begin{array}{l}0.671^{* * * *} \\
(0.041)\end{array}$ & $\begin{array}{l}0.664^{* * *} \\
(0.045)\end{array}$ & $\begin{array}{l}0.632^{* * *} \\
(0.047)\end{array}$ \\
\hline $\log S_{\text {it- } 1}$ & $\begin{array}{l}0.003 \\
(0.009)\end{array}$ & $\begin{array}{l}-0.137^{* * * *} \\
(0.030)\end{array}$ & $\begin{array}{l}-0.021^{*} \\
(0.012)\end{array}$ & $\begin{array}{l}0.014 \\
(0.009)\end{array}$ & $\begin{array}{l}-0.009 \\
(0.010)\end{array}$ & $\begin{array}{l}-0.127^{* * * *} \\
(0.031)\end{array}$ & $\begin{array}{l}-0.037^{* * * *} \\
(0.013)\end{array}$ & $\begin{array}{l}0.002 \\
(0.010)\end{array}$ \\
\hline asset growth $_{\text {it-1 }}$ & $\begin{array}{l}-0.231^{* * *} \\
(0.031)\end{array}$ & $\begin{array}{l}-0.226^{* * *} \\
(0.030)\end{array}$ & $\begin{array}{l}-0.231^{* * *} \\
(0.032)\end{array}$ & $\begin{array}{l}-0.249^{* * *} \\
(0.030)\end{array}$ & $\begin{array}{l}-0.197^{* * *} \\
(0.027)\end{array}$ & $\begin{array}{l}-0.168^{* * *} \\
(0.026)\end{array}$ & $\begin{array}{l}-0.186^{* * *} \\
(0.027)\end{array}$ & $\begin{array}{l}-0.159^{* * *} \\
(0.025)\end{array}$ \\
\hline tangibility $_{\mathrm{it}-1}$ & $\begin{array}{l}0.666^{* * *} \\
(0.113)\end{array}$ & $\begin{array}{l}0.935^{* * *} \\
(0.130)\end{array}$ & $\begin{array}{l}0.803^{* * * *} \\
(0.133)\end{array}$ & $\begin{array}{l}0.693^{* * *} \\
(0.115)\end{array}$ & $\begin{array}{l}0.949^{* * *} \\
(0.139)\end{array}$ & $\begin{array}{l}1.049^{* * *} \\
(0.150)\end{array}$ & $\begin{array}{l}1.016^{* * * *} \\
(0.159)\end{array}$ & $\begin{array}{l}0.869^{* * *} \\
(0.139)\end{array}$ \\
\hline roa $_{\text {it-1 }}$ & $\begin{array}{l}-0.517^{* *} \\
(0.200)\end{array}$ & $\begin{array}{l}-0.338^{*} \\
(0.192)\end{array}$ & $\begin{array}{l}-0.451^{* *} \\
(0.196)\end{array}$ & $\begin{array}{l}-0.314^{*} \\
(0.170)\end{array}$ & $\begin{array}{l}-0.321 \\
(0.195)\end{array}$ & $\begin{array}{l}-0.225 \\
(0.175)\end{array}$ & $\begin{array}{c}-0.241 \\
(0.176)\end{array}$ & $\begin{array}{l}-0.223 \\
(0.168)\end{array}$ \\
\hline $\operatorname{dep}_{\text {it-1 }}$ & $\begin{array}{l}-5.968^{* * *} \\
(0.952)\end{array}$ & $\begin{array}{l}-6.077^{\text {**** }} \\
(0.925)\end{array}$ & $\begin{array}{l}-5.380^{* * *} \\
(0.942)\end{array}$ & $\begin{array}{l}-6.147^{* * *} \\
(1.003)\end{array}$ & $\begin{array}{l}-7.885^{* * *} \\
(1.279)\end{array}$ & $\begin{array}{l}-6.909^{* * *} \\
(1.238)\end{array}$ & $\begin{array}{l}-7.267^{* * *} \\
(1.331)\end{array}$ & $\begin{array}{l}-6.737^{\text {*** }} \\
(1.196)\end{array}$ \\
\hline $\log t f p_{i t-1}$ & $\begin{array}{l}0.226^{\text {**** }} \\
(0.068)\end{array}$ & $\begin{array}{l}4.226^{* * * *} \\
(0.796)\end{array}$ & $\begin{array}{l}0.914^{* * * *} \\
(0.231)\end{array}$ & & $\begin{array}{l}0.204^{* *} \\
(0.084)\end{array}$ & $\begin{array}{l}3.568^{* * *} \\
(0.866)\end{array}$ & $\begin{array}{l}0.848^{* * *} \\
(0.278)\end{array}$ & \\
\hline labour intensity ${ }_{\text {it- } 1}$ & & & & $\begin{array}{l}0.595^{* *} \\
(0.261)\end{array}$ & & & & $\begin{array}{l}0.594^{* * * *} \\
(0.195)\end{array}$ \\
\hline $\log \operatorname{lp}_{\mathrm{it}-1}$ & & & & $\begin{array}{l}0.048^{* * * *} \\
(0.017)\end{array}$ & & & & $\begin{array}{l}0.042^{* * *} \\
(0.020)\end{array}$ \\
\hline m3 (p-value) & & & & & 0.692 & 0.872 & 0.764 & 0.729 \\
\hline m4 (p-value) & 0.228 & 0.153 & 0.201 & 0.187 & & & & \\
\hline $\mathrm{J}$ (Hansen) & 0.092 & 0.099 & 0.050 & 0.163 & 0.686 & 0.343 & 0.526 & 0.997 \\
\hline IVs (lags) & $\mathrm{t}-4, \ldots$ & $\mathrm{t}-4, \ldots$ & $\mathrm{t}-4, \ldots$ & $\mathrm{t}-4, \ldots$ & $\mathrm{t}-3, \ldots$ & $\mathrm{t}-3, \ldots$ & $\mathrm{t}-3, \ldots$ & $\mathrm{t}-3, \ldots$ \\
\hline & $\Delta \mathrm{t}-3 \ldots$ & $\Delta \mathrm{t}-3 \ldots$ & $\Delta \mathrm{t}-3 \ldots$ & $\Delta \mathrm{t}-3 \ldots$ & $\Delta \mathrm{t}-2 \ldots$ & $\Delta \mathrm{t}-2 \ldots$ & $\Delta \mathrm{t}-2 \ldots$ & $\Delta \mathrm{t}-2 \ldots$ \\
\hline number of observations & 13,652 & 13,656 & 13,656 & 13,653 & 6468 & 6471 & 6471 & 6470 \\
\hline
\end{tabular}

Notes: see notes to Tables 1 and 2. 
Table A8

The effect of productivity (moving average) on new equity.

\begin{tabular}{|c|c|c|c|c|c|c|c|c|}
\hline \multirow[t]{3}{*}{ Dependent variable: new equity ${ }_{\text {it }}$} & \multicolumn{4}{|l|}{ All } & \multicolumn{4}{|l|}{ Private } \\
\hline & LP & Wooldridge & ACF & Labour productivity & LP & Wooldridge & ACF & Labour productivity \\
\hline & (1) & (2) & (3) & (4) & (5) & (6) & (7) & $(8)$ \\
\hline new equity ${ }_{i, t-1}$ & $\begin{array}{l}0.026 \\
(0.023)\end{array}$ & $\begin{array}{l}0.006^{* * * *} \\
(0.022)\end{array}$ & $\begin{array}{l}0.011^{\text {***** }} \\
(0.022)\end{array}$ & $\begin{array}{l}0.010 \\
(0.023)\end{array}$ & $\begin{array}{l}0.029 \\
(0.032)\end{array}$ & $\begin{array}{l}0.041 \\
(0.034)\end{array}$ & $\begin{array}{l}0.066^{*} \\
(0.035)\end{array}$ & $\begin{array}{l}0.085^{* *} \\
(0.037)\end{array}$ \\
\hline $\log S_{\text {it-1 }}$ & $\begin{array}{l}-0.031 \\
(0.007)\end{array}$ & $\begin{array}{l}-0.174^{* * * *} \\
(0.024)\end{array}$ & $\begin{array}{l}-0.073^{* * *} \\
(0.011)\end{array}$ & $\begin{array}{l}-0.048^{* * * *} \\
(0.009)\end{array}$ & $\begin{array}{l}-0.049^{* * *} \\
(0.012)\end{array}$ & $\begin{array}{l}-0.255^{* * * *} \\
(0.050)\end{array}$ & $\begin{array}{l}-0.110^{* * * *} \\
(0.021)\end{array}$ & $\begin{array}{l}-0.062^{* * * *} \\
(0.016)\end{array}$ \\
\hline asset growth ${ }_{\text {it- } 1}$ & $\begin{array}{l}-0.046^{*} \\
(0.031)\end{array}$ & $\begin{array}{l}-0.054^{* *} \\
(0.022)\end{array}$ & $\begin{array}{l}-0.067^{* * * *} \\
(0.023)\end{array}$ & $\begin{array}{l}-0.050^{* *} \\
(0.020)\end{array}$ & $\begin{array}{l}-0.104^{* * *} \\
(0.028)\end{array}$ & $\begin{array}{l}-0.126^{* * * *} \\
(0.037)\end{array}$ & $\begin{array}{l}-0.149^{* * * *} \\
(0.038)\end{array}$ & $\begin{array}{l}-0.104^{* * *} \\
(0.037)\end{array}$ \\
\hline tangibility $_{i t-1}$ & $\begin{array}{l}0.165 \\
(0.127)\end{array}$ & $\begin{array}{l}0.397^{* * * *} \\
(0.109)\end{array}$ & $\begin{array}{l}0.462^{* * * *} \\
(0.120)\end{array}$ & $\begin{array}{l}0.011 \\
(0.118)\end{array}$ & $\begin{array}{l}0.265 \\
(0.202)\end{array}$ & $\begin{array}{l}0.774^{* * * *} \\
(0.252)\end{array}$ & $\begin{array}{l}0.870^{* * * *} \\
(0.271)\end{array}$ & $\begin{array}{l}0.463^{*} \\
(0.242)\end{array}$ \\
\hline roa $_{\text {it-1 }}$ & $\begin{array}{l}0.405^{\text {** }} \\
(0.199)\end{array}$ & $\begin{array}{l}0.399^{* *} \\
(0.161)\end{array}$ & $\begin{array}{l}0.416^{* * *} \\
(0.162)\end{array}$ & $\begin{array}{l}0.333^{*} \\
(0.174)\end{array}$ & $\begin{array}{l}0.473^{* *} \\
(0.233)\end{array}$ & $\begin{array}{l}-0.351 \\
(0.229)\end{array}$ & $\begin{array}{l}1.054^{* * * *} \\
(0.284)\end{array}$ & $\begin{array}{l}0.703^{* *} \\
(0.293)\end{array}$ \\
\hline dep $_{\text {it-1 }}$ & $\begin{array}{l}1.036 \\
(1.030)\end{array}$ & $\begin{array}{l}1.160 \\
(0.864)\end{array}$ & $\begin{array}{l}0.818 \\
(0.824)\end{array}$ & $\begin{array}{l}2.492^{* * * *} \\
(0.956)\end{array}$ & $\begin{array}{l}0.641 \\
(1.562)\end{array}$ & $\begin{array}{l}-5.455^{* * * *} \\
(1.718)\end{array}$ & $\begin{array}{c}-1.508 \\
(2.217)\end{array}$ & $\begin{array}{l}0.626 \\
(2.127)\end{array}$ \\
\hline $\operatorname{logtf} \mathrm{p}_{\mathrm{it}-1}$ & $\begin{array}{l}0.123^{* *} \\
(0.061)\end{array}$ & $\begin{array}{l}3.959^{* * * *} \\
(0.608)\end{array}$ & $\begin{array}{l}1.149^{* * * *} \\
(0.179)\end{array}$ & & $\begin{array}{l}0.225^{* *} \\
(0.088)\end{array}$ & $\begin{array}{c}-0.667 \\
(1.545)\end{array}$ & $\begin{array}{l}1.400^{* * * *} \\
(0.303)\end{array}$ & \\
\hline labour intensity ${ }_{\mathrm{it}-1}$ & & & & $\begin{array}{c}-0.044 \\
(0.255)\end{array}$ & & & & $\begin{array}{l}0.668^{* *} \\
(0.317)\end{array}$ \\
\hline $\log \mathrm{p}_{\mathrm{it}-1}$ & & & & $\begin{array}{l}0.068^{* * * *} \\
(0.016)\end{array}$ & & & & $\begin{array}{l}0.108^{* * * *} \\
(0.020)\end{array}$ \\
\hline m3 (p-value) & 0.672 & 0.745 & 0.569 & 0.260 & 0.206 & 0.699 & 0.388 & 0.199 \\
\hline $\mathrm{J}$ (Hansen) & 0.039 & 0.169 & 0.114 & 0.118 & 0.607 & 0.392 & 0.328 & 0.555 \\
\hline IVs (lags) & $\mathrm{t}-3, \ldots$ & $\mathrm{t}-3, \ldots$ & $\mathrm{t}-3, \ldots$ & $\mathrm{t}-3, \ldots$ & $\mathrm{t}-3, \ldots$ & $\mathrm{t}-3, \ldots$ & $\mathrm{t}-3, \ldots$ & $\mathrm{t}-3, \ldots$ \\
\hline & $\Delta \mathrm{t}-2 \ldots$ & $\Delta \mathrm{t}-2 \ldots$ & $\Delta \mathrm{t}-2 \ldots$ & $\Delta \mathrm{t}-2 \ldots$ & $\Delta \mathrm{t}-2 \ldots$ & $\Delta \mathrm{t}-2 \ldots$ & $\Delta \mathrm{t}-2 \ldots$ & $\Delta \mathrm{t}-2 \ldots$ \\
\hline number of observations & 13,644 & 13,648 & 13,648 & 13,645 & 6468 & 6471 & 6471 & 6470 \\
\hline
\end{tabular}

Notes: see notes to Tables 1 and 2.

Table A9

The effect of productivity (moving average) on long-term debt.

\begin{tabular}{|c|c|c|c|c|c|c|c|c|}
\hline \multirow[t]{3}{*}{ Dependent variable: $\operatorname{ltd}_{\mathrm{it}}$} & \multicolumn{4}{|l|}{ All } & \multicolumn{4}{|l|}{ Private } \\
\hline & LP & Wooldridge & $\mathrm{ACF}$ & Labour productivity & LP & Wooldridge & $\mathrm{ACF}$ & Labour productivity \\
\hline & (1) & (2) & (3) & (4) & (5) & (6) & (7) & (8) \\
\hline $\operatorname{ltd}_{\mathrm{i}, \mathrm{t}-1}$ & $\begin{array}{l}0.689^{* * *} \\
(0.029)\end{array}$ & $\begin{array}{l}0.676^{* * * *} \\
(0.029)\end{array}$ & $\begin{array}{l}0.675^{* * *} \\
(0.030)\end{array}$ & $\begin{array}{l}0.010 \\
(0.023)\end{array}$ & $\begin{array}{l}0.616^{* * * *} \\
(0.050)\end{array}$ & $\begin{array}{l}0.535^{* * * *} \\
(0.047)\end{array}$ & $\begin{array}{l}0.537^{* * *} \\
(0.049)\end{array}$ & $\begin{array}{l}0.085^{* *} \\
(0.037)\end{array}$ \\
\hline $\log S_{\text {it- } 1}$ & $\begin{array}{l}-0.001 \\
(0.002)\end{array}$ & $\begin{array}{l}-0.012^{*} \\
(0.007)\end{array}$ & $\begin{array}{c}-0.004 \\
(0.003)\end{array}$ & $\begin{array}{l}-0.048^{* * * *} \\
(0.009)\end{array}$ & $\begin{array}{l}0.007^{* * *} \\
(0.003)\end{array}$ & $\begin{array}{l}-0.017^{*} \\
(0.009)\end{array}$ & $\begin{array}{l}-0.003 \\
(0.004)\end{array}$ & $\begin{array}{l}-0.062^{* * *} \\
(0.016)\end{array}$ \\
\hline asset growth ${ }_{\text {it- } 1}$ & $\begin{array}{l}-0.013 \\
(0.008)\end{array}$ & $\begin{array}{l}-0.020^{\text {**** }} \\
(0.007)\end{array}$ & $\begin{array}{l}-0.021^{* * *} \\
(0.007)\end{array}$ & $\begin{array}{l}-0.050^{* *} \\
(0.020)\end{array}$ & $\begin{array}{l}-0.019^{*} \\
(0.011)\end{array}$ & $\begin{array}{l}-0.021^{* *} \\
(0.008)\end{array}$ & $\begin{array}{l}-0.024^{* * *} \\
(0.007)\end{array}$ & $\begin{array}{l}-0.104^{* * *} \\
(0.037)\end{array}$ \\
\hline tangibility $_{\mathrm{it}-1}$ & $\begin{array}{l}0.076^{* *} \\
(0.030)\end{array}$ & $\begin{array}{l}0.092^{* * *} \\
(0.028)\end{array}$ & $\begin{array}{l}0.104^{* * * *} \\
(0.028)\end{array}$ & $\begin{array}{l}0.011 \\
(0.118)\end{array}$ & $\begin{array}{l}0.033 \\
(0.041)\end{array}$ & $\begin{array}{l}0.083^{*} \\
(0.043)\end{array}$ & $\begin{array}{l}0.085^{*} \\
(0.047)\end{array}$ & $\begin{array}{l}0.463^{*} \\
(0.242)\end{array}$ \\
\hline roa $_{\text {it-1 }}$ & $\begin{array}{l}0.129^{* *} \\
(0.056)\end{array}$ & $\begin{array}{l}0.130^{* * *} \\
(0.043)\end{array}$ & $\begin{array}{l}0.137^{* * *} \\
(0.044)\end{array}$ & $\begin{array}{l}0.333^{*} \\
(0.174)\end{array}$ & $\begin{array}{l}0.034 \\
(0.070)\end{array}$ & $\begin{array}{l}0.088 \\
(0.054)\end{array}$ & $\begin{array}{l}0.073 \\
(0.052)\end{array}$ & $\begin{array}{l}0.703^{* *} \\
(0.293)\end{array}$ \\
\hline dep $_{\text {it }-1}$ & $\begin{array}{l}-0.511^{* *} \\
(0.215)\end{array}$ & $\begin{array}{l}-0.557^{\text {**** }} \\
(0.197)\end{array}$ & $\begin{array}{l}-0.628^{* * *} \\
(0.196)\end{array}$ & $\begin{array}{l}2.492^{* * * *} \\
(0.956)\end{array}$ & $\begin{array}{l}-0.815^{*} \\
(0.420)\end{array}$ & $\begin{array}{l}-0.919^{* * *} \\
(0.282)\end{array}$ & $\begin{array}{l}-0.971^{\text {**** }} \\
(0.286)\end{array}$ & $\begin{array}{l}0.626 \\
(2.127)\end{array}$ \\
\hline $\log t f p_{i t-1}$ & $\begin{array}{l}0.032^{*} \\
(0.018)\end{array}$ & $\begin{array}{l}0.348^{*} \\
(0.185)\end{array}$ & $\begin{array}{l}0.102^{* *} \\
(0.050)\end{array}$ & & $\begin{array}{l}0.008 \\
(0.023)\end{array}$ & $\begin{array}{l}0.644^{* * * *} \\
(0.242)\end{array}$ & $\begin{array}{l}0.172^{* *} \\
(0.072)\end{array}$ & \\
\hline labour intensity $y_{\mathrm{it}-1}$ & & & & $\begin{array}{c}-0.044 \\
(0.255)\end{array}$ & & & & $\begin{array}{l}0.668^{* *} \\
(0.317)\end{array}$ \\
\hline $\log l p_{i t-1}$ & & & & $\begin{array}{l}0.068^{* * * *} \\
(0.016)\end{array}$ & & & & $\begin{array}{l}0.108^{* * * *} \\
(0.020)\end{array}$ \\
\hline $\mathrm{m} 2$ (p-value) & & & & & 0.445 & & & \\
\hline m3 (p-value) & 0.257 & 0.346 & 0.346 & 0.260 & & 0.097 & 0.101 & 0.199 \\
\hline $\mathrm{J}$ (Hansen) & 0.391 & 0.210 & 0.177 & 0.118 & 0.529 & 0.118 & 0.191 & 0.555 \\
\hline IVs (lags) & $\mathrm{t}-3, \ldots$ & $\mathrm{t}-3, \ldots$ & $\mathrm{t}-3, \ldots$ & $\mathrm{t}-3, \ldots$ & $\mathrm{t}-2, \ldots$ & $\mathrm{t}-3, \ldots$ & $\mathrm{t}-3, \ldots$ & $\mathrm{t}-3, \ldots$ \\
\hline & $\Delta \mathrm{t}-2 \ldots$ & $\Delta \mathrm{t}-2 \ldots$ & $\Delta \mathrm{t}-2 \ldots$ & $\Delta \mathrm{t}-2 \ldots$ & $\Delta \mathrm{t}-1 \ldots$ & $\Delta \mathrm{t}-2 \ldots$ & $\Delta \mathrm{t}-2 \ldots$ & $\Delta \mathrm{t}-2 \ldots$ \\
\hline number of observations & 12,402 & 13,425 & 13,425 & 13,645 & 5564 & 6349 & 6349 & 6470 \\
\hline
\end{tabular}

Notes: see notes to Tables 1 and 2.

\section{References}

Ackerberg, D. A., Caves, K., \& Frazer, G. (2015). Identification properties of recent production function estimators. Econometrica, 83(6), 2411-2451.

Aghion, P., \& Howitt, P. (1998). Endogenous growth theory. Cambridge: MIT Press.
Allen, F., Qian, J., \& Qian, M. (2005). Law, finance and economic growth in China. Journal of Financial Economics, 77(1), 57-116.

Alti, A. (2006). How persistent is the impact of market timing on capital structure? Journal of Finance, 61(4), 1681-1710.

An, C., Pan, X., \& Tian, G. G. (2014). Ownership structure and collateral requirements: Evidence from China's listed firms. International Review of Financial Analysis, 36(4), 
$168-178$

Ayyagari, M., Demirgüç-Kunt, A., \& Maksimovic, V. (2011). Firm innovation in emerging markets: The role of finance, governance, and competition. Journal of Finance and Quantitative Analysis, 46, 1545-1580.

Baker, M., Stein, J. C., \& Wurgler, J. (2003). When does the market matter? Stock prices and the investment equity-dependent firms. The Quarterly Journal of Economics, 118(3), 969-1005.

Baker, M., \& Wurgler, J. (2002). Market timing and capital structure. Journal of Finance, 57(1), 1-32.

Bancel, F., \& Mittoo, U. R. (2004). Cross-country determinants of capital structure choice: A survey of European firms. Financial Management, 33(4), 103-132.

Barclay, M. J., \& Smith, C. W. (1995). "The Maturity Structure of Corporate Debt". The Journal of Finance, 50(2), 609-631.

Beck, T., Demirgüç-Kunt, A., Laeven, L., \& Maksimovic, V. (2006). The determinants of financing obstacles. Journal of International Money and Finance, 25(6), 932-952.

Beck, T., Demirgüç-Kunt, A., \& Levine, R. (2003). Law, endowments, and finance. Journal of Financial Economics, 70(2), 137-181.

Beck, T., Levine, R., \& Loayza, N. (2000). Finance and the source of growth. Journal of Financial Economics, 58(1-2), 261-300.

Billingsley, R. S., Smith, D. M., \& Lamy, R. E. (1994). Simultaneous debt and equity issues and capital structure targets. The Journal of Financial Research, 17(4), 495-516.

Bolton, P., Chen, H., \& Wang, N. (2013). Market timing, investment, and risk management. Journal of Financial Economics, 109(10), 40-62.

Booth, L., Aivazian, V., Demirgüç-Kunt, A., \& Maksimovic, V. (2001). Capital structure in developing countries. Journal of Finance, 56(1), 87-130.

Bradley, M., Jarrell, G. A., \& Kim, E. H. (1984). On the existence of an optimal capital structure: Theory and evidence. Journal of Finance, 39(3), 857-878.

Brealey, R., Leland, H. E., \& Pyle, D. H. (1977). Information asymmetries, financial structures and financial intermediaries. Journal of Finance, 32(2), 371-387.

Brown, J. R., Fazzari, S. M., \& Petersen, B. C. (2009). Financing innovation and growth: Cash flow, external equity, and the 1990s R\&D boom. Journal of Finance, 64(1), $151-185$.

Carlin, W., \& Mayer, C. (2003). Finance, investment and growth. Journal of Financial Economics, 69(1), 191-226.

Casey, E., \& O'Toole, C. M. (2014). Bank lending constraints, trade credit and alternative financing during the financial crisis: Evidence from European SMEs. Journal of Corporate Finance, 27(3), 173-193.

Chen, M., \& Guariglia, A. (2011). Financial constraints and firm productivity in China: Do liquidity and export behaviour make a difference? Leverhulme Centre for research on globalisation and economic policy, University of Nottingham, working paper 11/09.

Chen, M., \& Guariglia, A. (2013). Internal financial constraints and firm productivity in China: Do liquidity and export behaviour make a difference? Journal of Comparative Economics, 41(4), 1123-1140.

Crespí, R., \& Martín-Oliver, A. (2015). Do family firms have better access to external finance during crisis? Corporate Governance: An International Review, 23(3), 249-265.

DeAngelo, H., \& Masulis, R. W. (1980). Optimal capital structure under corporate and personal taxation. Journal of Financial Economics, 8(1), 3-29.

Ding, S., Kim, M., \& Zhang, X. (2018). Do firms care about investment opportunities? Evidence from China. Journal of Corporate Finance, 52, 214-237.

Egger, P. H., \& Keuschnigg, C. (2017). Access to credit and comparative advantage. Canadian Journal of Economics, 50(2), 481-505.

Fama, E. F. (1984). What's different about banks? Journal of Monetary Economics, 15(1), 29-39.

Fama, E. F., \& French, K. R. (2002). Testing trade-off and pecking order predictions about dividends and debt. The Review of Financial Studies, 15(1), 1-33.

Feng, L., Fu, T., \& Kutan, A. M. (2019). Can government intervention be both a curse and a blessing? Evidence from China's finance sector. International Review of Financial Analysis, 61(1), 71-81.

Ferrando, A., \& Ruggieri, A. (2018). Financial constraints and productivity: Evidence from euro area companies. International Journal of Finance and Economics, 23(3), $257-282$.

Ferri, M. G., \& Jones, W. H. (1979). Determinants of financial structure: A new methodological approach. Journal of Finance, 34(3), 631-644.

Frank, M. Z., \& Goyal, V. K. (2003). Testing the pecking order theory of capital structure. Journal of Financial Economics, 67(2), 217-248.

Gatti, R., \& Love, I. (2008). Does access to credit improve productivity? Evidence from Bulgaria. The Economics of Transition, 16(3), 445-465.

Gonzalez, L., \& James, C. (2007). Banks and bubbles: How good are bankers at spotting winners? Journal of Financial Economics, 86(1), 40-70.

Guariglia, A., Liu, X., \& Song, L. (2011). Internal finance and growth: Microeconomic evidence on Chinese firms. Journal of Development Economics, 96(1), 79-94.

Heaton, J. B. (2002). Managerial optimism and corporate finance. Financial Management, $31(2), 33-45$.

Heil, M. (2018). Finance and productivity: A literature review. Journal of Economic Surveys, 32(5), 1355-1383.

Hovakimian, A. (2006). Are observed capital structures determined by equity market timing? Journal of Financial and Quantitative Analysis, 41(1), 221-243.

Huang, G. H., \& Song, F. M. (2006). The determinants of capital structure: Evidence from China. China Economic Review, 17(1), 14-36.

Imrohoroglu, A., \& Tüzel, S. (2014). Firm-level productivity, risk, and return. Management
Science, 60(8), 2073-2090.

Jensen, M. (1986). Agency costs of free cash flow, corporate finance, and takeovers. American Economic Review, 76(2), 323-360.

Jensen, M., \& Meckling, W. (1976). Theory of the firm: Managerial behaviour, agency costs and ownership structure. Journal of Financial Economics, 3(4), 305-360.

Johan, S. A., \& Wu, Z. (2014). Does the quality of lender-borrower relationships affect small business access to debt? Evidence from Canada and implications in China. International Review of Financial Analysis, 36(4), 206-211.

King, R. G., \& Levine, R. (1993). Finance and growth: Schumpeter might be right. Quarterly Journal of Economics, 108(3), 717-737.

Krishnan, K., Nandy, D. K., \& Puri, M. (2015). Does financing spur small business productivity? Evidence from a natural experiment. The Review of Financial Studies, 28(6), 1768-1809.

Krugman, P. (1990, 1994, 1997), The age of diminished expectations, first, second, third ed. MIT press.

Leary, M. T., \& Roberts, M. R. (2010). The pecking order, debt capacity, and information asymmetry. Journal of Financial Economics, 95(3), 332-355.

Levinsohn, J., \& Petrin, A. (2003). Estimating production functions using inputs to control unobservables. Review of Economic Studies, 70(2), 317-341.

Mande, V., Park, Y. K., \& Son, M. (2011). Equity of debt finance: Does good corporate governance matter? Corporate Governance: An International Review, 20(2), 195-211.

Melitz, M. J. (2003). The impact of trade on intra-industry reallocations and aggregate industry productivity. Econometrica, 71(6), 1695-1725.

Morellec, E. (2004). Can managerial discretion explain observed leverage ratio? Review of Financial Studies, 17(1), 257-294.

Moreno-Badia, M., \& Slootmaekers, V. (2009). The missing link between financial constraints and productivity. International Monetary Fund (Working Paper No. WP/09/72).

Muûls, M. (2015). Exporters, importers and credit constraints. Journal of International Economics, 95(2), 333-343.

Myers, S. C. (1977). Determinants of corporate borrowing. Journal of Financial Economics, $5(2), 147-175$

Myers, S. C., \& Majluf, N. S. (1984). Corporate financing and investment decisions when firms have information that investors do not have. Journal of Financial Economics, 13(2), 187-221.

Neuhann, D., \& Saidi, F. (2018). Do universal banks finance riskier but more productive firms? Journal of Financial Economics, 128(1), 66-85.

Olley, G. S., \& Pakes, A. (1996). The dynamics of productivity in the telecommunications equipment industry. Econometrica, 64(6), 1263-1297.

Ovtchinnikov, A. V. (2010). Capital structure decisions: Evidence from deregulated industries. Journal of Financial Economics, 95(2), 249-274.

Öztekin, Ö., \& Flannery, M. J. (2012). Institutional determinants of capital structure adjustment speeds. Journal of Financial Economics, 103(1), 88-112.

Poncet, S., Steingress, W., \& Vandenbussche, H. (2010). Financial constraints in China: Firm-level evidence. China Economic Review, 21(3), 411-422.

Rajan, R. G., \& Zingales, L. (1995). What do we know about capital structure? Some evidence from international data. Journal of Finance, 50(5), 1421-1460.

Romer, P. (1990). Endogenous technological change. Journal of Political Economy, 94(5), 1002-1037.

Ross, S. A. (1977). The determinants of financial structure: The incentive-signalling approach. The Bell Journal of Economics, 8(1), 23-40.

Sarkar, S., \& Zapatero, F. (2003). The trade-off model with mean reverting earnings: Theory and empirical tests. The Economic Journal, 113(490), 834-860.

Smith, C. W., Jr., \& Watts, R. L. (1992). The investment opportunity set and corporate financing, dividend, and compensation policies. Journal of Financial Economics, 32(3), 263-292.

Song, Z., Storesletten, K., \& Zilobotti, F. (2011). Growing like China. American Economic Review, 101(1), 196-233.

Stulz, R. M., \& Johnson, H. (1985). An analysis of secured debt. Journal of Financial Economics, 14(4), 501-521.

Sundaresan, S., Wang, N., \& Yang, J. (2015). Dynamic investment, capital structure, and debt overhang. Review of Corporate Finance Studies, 4(1), 1-42.

Syverson, C. (2011). What determines productivity? Journal of Economic Literature, 49(2), 326-365.

Tan, Y., Zhu, Z., Zeng, C., \& Gao, M. (2014). Does external finance pressure affect corporate disclosure of Chinese non-state-owned enterprises? International Review of Financial Analysis, 36(4), 212-222.

Titman, S., \& Wessels, R. (1988). The determinants of capital structures choice. Journal of Finance, 43(1), 1-19.

Vanacker, T., Heughebaert, A., \& Manigart, S. (2014). Institutional frameworks, venture capital and the financing of European new technology-based firms. Corporate Governance: An International Review, 22(3), 199-215.

Wagner, J. (2014). Credit constraints and exports: A survey of empirical studies using firm-level data. Industrial and Corporate Change, 23(6), 1477-1492.

Warner, J. B. (1977). Bankruptcy costs: Some evidence. Journal of Finance, 32(2), 337-348.

Wooldridge, J. M. (2009). On estimating firm-level, production functions using proxy variables to control for unobservables. Economics Letters, 104(3), 112-114.

Zwiebel, J. (1996). Dynamic capital structure under managerial entrenchment. American Economic Review, 86(5), 1197-1215. 